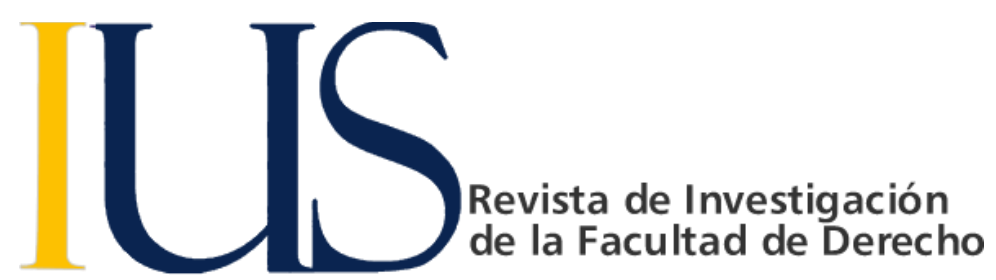

\title{
Apuntes para la historia constitucional peruana. La Constitución de 1920, cien años después.
}

\author{
Freddy Ronald Centurión González ${ }^{1}$
}

\begin{tabular}{|c|c|}
\hline INFORMACIÓN DEL ARTÍCULO & RESUMEN \\
\hline $\begin{array}{l}\text { Historia del artículo: } \\
\text { Recibido el } 9 \text { de julio } 2020 \\
\text { Aceptado el } 17 \text { julio } 2020\end{array}$ & \multirow{2}{*}{$\begin{array}{l}\text { Dentro de la historia del Perú, la segunda etapa gubernativa de Augusto B. Leguía } \\
\text { (1919-1930), llamado el "oncenio", no deja de ser un periodo polémico por sus luces y } \\
\text { sombras. Surgido de un golpe de estado, el régimen implementó una reforma } \\
\text { constitucional que derogó el texto de } 1860 \text { en favor de una nueva Constitución, la de } \\
\text { 1920. Aprovechando el centenario de dicho texto, que dio inicio al constitucionalismo } \\
\text { social en el Perú, este artículo busca brindar un acercamiento a las circunstancias que } \\
\text { marcaron su origen y derogación, las reformas que implementó, y su continuidad en el } \\
\text { tiempo }\end{array}$} \\
\hline $\begin{array}{l}\text { Palabras clave: } \\
\text { Derecho constitucional peruano, } \\
\text { Evolución constitucional peruana, } \\
\text { Historia del Derecho peruano, }\end{array}$ & \\
\hline
\end{tabular}

"Oncenio" de Leguía

Notes for the Peruvian constitutional history. The 1920 Constitution, one hundred years later

\section{ABSTRACT}

Keywords:

Peruvian constitutional law, Peruvian constitutional evolution, History of peruvian law, Leguía's "Oncenio"
Within the history of Peru, the second stage of government of Augusto B. Leguía (1919-1930), called the "oncenio", is still a controversial period for its lights and shadows. Emerged from a coup d'état, the regime implemented a constitutional reform that repealed the text of 1860 in favor of a new Constitution, that of 1920. Taking advantage of the centenary of that text, which started social constitutionalism in Peru, this article seeks provide an approach to the circumstances that marked its origin and repeal, the reforms it implemented, and its continuity over time.

\section{Sumario}

Introducción. 1. Los inicios del siglo XX. 2. La Asamblea Nacional de 1919. 2.1. El plebiscito constitucional. 2.2. El debate constitucional. 3. La Constitución de 1920. 3.1. El Estado y la Nación. 3.2. Los derechos fundamentales. 3.2.1. Las "garantías nacionales". 3.2.2. Las "garantías individuales". 3.2.3. Las "garantías sociales". 3.3. La descentralización. 3.3.1. Los Congresos Regionales. 3.3.2. Las Municipalidades. 3.4. Los poderes del Estado. 3.4.1. El Poder Legislativo. 3.4.2. El Poder Ejecutivo. 3.4.3. El Poder Judicial. 4. La conculcación de la Constitución. 4.1. La visión de Estado de Leguía. 4.2.
El autoritarismo y las reelecciones. 5. La impronta de la Constitución de 1920 en el constitucionalismo peruano 5.1. La relación entre el Ejecutivo y el Legislativo. 5.2. La reelección presidencial. 5.3. La independencia judicial. 5.4. La descentralización. 5.5. La situación del indígena. 5.6. Las propuestas rechazadas en 1919. Conclusiones. Bibliografía.

\section{Introducción}

El desafío del siglo XIX peruano fue la configuración de un Estado moderno con una sólida tradición republicana, es decir, con el respeto irrestricto de la

\footnotetext{
${ }^{1}$ Abogado. Docente adscrito a la Facultad de Derecho de la Universidad Católica Santo Toribio de Mogrovejo. Chiclayo, Perú. Email: fcenturion@usat.edu.pe ORCID: https://orcid.org /0000-0002-1977-3762
} 
Constitución y las leyes. Sin embargo, las dictaduras, el caudillismo y los problemas de la realidad peruana, terminaron por impedir la vigencia plena del constitucionalismo, impidiendo la democracia, desdeñando la voluntad popular (Jamanca, 2015). Tal situación hizo difícil definir una serie de aspectos que debía encarar el Perú. Consecuentemente, las constituciones peruanas fueron utópicas, tuvieron una vigencia fugaz, por estar adecuadas a los intereses del gobierno de turno, ya sea liberal o conservador. Después de ardorosos debates ideológicos, en 1860 se promulgó una Constitución que representaba un retroceso en el liberalismo del texto de 1856, en aras de una transacción con los grupos conservadores.

La Carta de 1860 continuó con la tendencia de su predecesora de 1856 de introducir instituciones del parlamentarismo para contrapesar el poder presidencial, estableció el Estado liberal inspirado en la división de poderes y la soberanía popular, a la par que enumeraba minuciosamente las garantías individuales para proteger al individuo frente al Estado. Si bien dio un golpe parlamentario para emprender la reforma constitucional, el Congreso de 1860 actuó por razones prácticas y de necesidad nacional. La vigencia de la Constitución resultante, pese a la crisis política de los años 1870 y a la desastrosa guerra con Chile, fue quizá la mejor justificación del trabajo del Congreso de 1860. Sin embargo, las demandas reformistas en el Perú de la segunda década del siglo XX, condujeron al retorno al poder del expresidente Augusto B. Leguía, que tomó el poder con un golpe de estado en 1919. Su gestión de gobierno, denominada el "Oncenio", se extendió hasta 1930, en una etapa de grandes cambios políticos, económicos, sociales y culturales. Dicho periodo, para bien y para mal, marcó el Perú contemporáneo: se legisló la cuestión indígena por primera vez en la historia republicana, se desarrolló un ambicioso programa de modernización, se expandió el Estado hacia un rol intervencionista y promotor, se pasó de la hegemonía económica británica a la norteamericana, se produjo una gran explosión cultural con la llamada "generación del Centenario", surgieron ideologías políticas que marcarían el Perú del siglo XX... y se reformó la vieja Constitución de 1860.

\section{LOS INICIOS DEL SIGLOXX}

De forma similar al resto del continente de comienzos del siglo XX, el Perú vivió una continuidad de gobiernos constitucionales sobre la base del Partido Civil, fundado inicialmente por Manuel Pardo en 1871, en receso durante la guerra con Chile y en los años de la reconstrucción, y revitalizado a partir de 1896. Se avanzó en la construcción de un Estado más técnico y eficiente, dejando de lado los últimos restos de la legislación virreinal, se reorganizó los regímenes tributario y hacendario, se impulsó la educación y las medidas de higiene, y hasta existen estadísticas que indicarían que la población parecía no sufrir excesivas estrecheces. Los rivales del civilismo le achacaban su carácter "señorial" y su identificación con los sectores terratenientes. Puesto que no podía achacársele de dictatorial, salvo quizá algunas situaciones extremas, la mejor forma de atacar al Partido Civil era desde la óptica social, al punto de identificar (con más fuerza después de los años 1930) "civilismo" con "oligarquía" (Pease, 1995).

Sin embargo, la crítica que se podía hacer estribaba en los problemas derivados del mal funcionamiento de las instituciones electorales y la falta de adecuadas respuestas frente a los cambios sociales. Y es que, al no funcionar adecuadamente el sufragio, poco a poco, se vería a las sublevaciones como movimientos plebiscitarios destinados a reafirmar la voluntad pública impedida de expresarse por los medios legales (Basadre, 2005).

Entre 1903 y 1912, se sucedieron cuatro civilistas en el poder: Manuel Candamo, quien murió tras menos de un año en el cargo; su segundo vicepresidente Serapio Calderón, que convocó a elecciones conforme con el artículo $91^{\circ}$ de la Constitución de 1860; José Pardo, hijo del fundador del civilismo, canciller de Candamo, exponente de los jóvenes del partido; y Augusto B. Leguía, ministro de Hacienda de Candamo y Pardo.

Dicha continuidad no solo se puede explicar en base a la manipulación del sufragio, sino al hecho de que, a diferencia del opositor Partido Demócrata de Nicolás de Piérola, el Partido Civil no tuvo un caudillo único. Durante su hegemonía, dentro del civilismo se pueden identificar, al menos tres alas políticas distintas: el "neopardismo" representando los intereses de los agroexportadores, el "pradismo" personificando los intereses de la banca e industria, y desde 1909 el "leguiísmo" encarnando las aspiraciones de los profesionales y clases medias (Altuve, 2006). Estas facciones entraron en colisión en dos ocasiones, llegando al punto de ruptura. La primera fue por razones generacionales en 1904, entre los fundadores y los jóvenes del partido en torno a la sucesión del presidente Candamo; la segunda tuvo matices más personales y doctrinarios en 1911, debido a las repercusiones del personalismo del presidente Leguía (Guerra, 1994).

Nacido en Lambayeque en 1863, Leguía no provenía de la élite limeña, pero supo abrirse paso gracias a su habilidad como financista y a un matrimonio ventajoso. Dirigente de un sector moderno dentro del civilismo, 
como ministro de Hacienda, buscó impulsar la economía peruana, pero su audacia y su energía alarmaron a los sectores conservadores de su partido (Karno, 1970).

Leguía destaca por una personalidad sumamente fuerte, ciertas dotes caudillistas, aunque de estilo diferente a Piérola como caudillo civil. Leguía añade a su aptitud política una mente fría y calculadora que le permite planificar sus adhesiones, sus alianzas y sus manejos para conseguir neutralizar a enemigos, deshacerlos o ganarlos a su causa. Fue un gran conocedor de la psicología humana y de los políticos de su tiempo. Amante de los halagos, al igual que Piérola, pero controla su egolatría hasta convertirla rentable políticamente (Guerra, 1994, p. 41).

Inicialmente, pareció que su gobierno sería una continuación del orden civilista, pero pronto Leguía demostró independencia de sus protectores, especialmente luego de un secuestro frustrado en mayo de 1909 por los demócratas. Su política represiva le atrajo la oposición, tanto de las añejas montoneras demócratas, como de los parlamentarios de su propio partido. Leguía no se doblegó y mediante medidas arbitrarias deshizo la Junta Electoral Nacional en 1911, e incorporó un tercio de parlamentarios para poder gobernar. De esta manera, su figura terminó dividiendo al civilismo.

Con los partidos en crisis, las elecciones de 1912 fueron sumamente agitadas, al punto que el Congreso eligió al nuevo presidente. Guillermo Billinghurst, antiguo lugarteniente de Piérola, estrenó una especie de régimen demagógico y plebiscitario; las reformas que propuso encontraron una tenaz oposición en el Congreso, controlado por el civilismo (con predominio de la facción leguíista), lo que derivó en una pugna entre ambos poderes (Paniagua, 2004). Esa pugna llegó a su clímax en 1914, llevando a Billinghurst a planear la disolución del Congreso y la reforma de la Constitución de 1860 a través de un proceso plebiscitario. Tal empeño llevó al golpe de estado del 4 de febrero de 1914, seguido de la polémica sesión parlamentaria del 15 de mayo de 1914, con la que se designó Presidente Provisorio al coronel Oscar R. Benavides, cortando la ordenada sucesión civil existente desde 1895 (Centurión, 2014).

Benavides fue sucedido por el expresidente José Pardo en agosto de 1915, pero la polarización política que se vivía desde la crisis de 1914, impidió al nuevo gobernante hacer una gestión notable como en su anterior mandato. El desgaste del civilismo, los sonados crímenes políticos de los diputados Rafael Grau y Augusto Ugarte en 1917, el malestar económico y social producto de la Primera Guerra Mundial, el alza del costo de vida, la creciente presión de los sindicatos, la agitación entra la juventud universitaria, la inquietud en varios sectores del ejército y la crisis de los partidos tradicionales, fueron algunos de los problemas con los que Pardo debió lidiar. Todo este panorama le otorgaba a la figura de Augusto B. Leguía, desterrado desde 1913, una fuerza cada vez mayor, resaltada por su innegable oposición al civilismo, al que se achacaba los males del Perú. Desde su exilio en Londres, Leguía, a la par que era testigo de la Primera Guerra Mundial, planeaba su retorno al poder, para lo cual, armó una amplia correspondencia con actores políticos y militares descontentos con el civilismo pardista.

El regreso de Leguía en febrero de 1919 fue apoteósico. Logró pronto aglutinar en torno suyo a los grupos marginados por el civilismo, y además logró la adhesión de los grupos obreros y universitarios, al apoyar abiertamente sus demandas reformistas. Era el seguro ganador de las elecciones de mayo de 1919; pero como en las elecciones, se presentaron varias irregularidades, correspondió al Congreso, con mayoría civilista, el ratificar los resultados de la Junta Electoral y la Corte Suprema, anulando varias actas que favorecían al candidato Leguía.

Aduciendo un posible fraude electoral, pese a las declaraciones en sentido contrario del presidente Pardo, y contando con el respaldo de las fuerzas armadas, Leguía decidió actuar y la madrugada del 4 de julio de 1919, la gendarmería ingresó a Palacio y arrestó al presidente Pardo. Al mediodía, Leguía juró como Presidente Provisorio ante el héroe de la Breña, general Cáceres (De la Barra, 1967). Si bien con la crisis de 1914, el Ejército interrumpió la ordenada sucesión presidencial, los militares volvieron a la escena pública del siglo XX de forma definitiva con el golpe de 1919. Si bien no hubo un caudillo militar en la cumbre que apoyase al Oncenio, el aparato represivo policial y militar, debelando constantes conspiraciones, indicaban que el Ejército seguía presente (Planas, 1994). No sólo se apresó y desterró al presidente Pardo, sino que se disolvió al Congreso, acabando con la continuidad parlamentaria existente desde 1895, y de paso, desconoció el tercio elegido en mayo de 1919. Era obvio que Leguía no toleraría más obstrucciones a su gobierno, como la que le hizo el bloque civilista en su primer gobierno. Más que un golpe contra Pardo, a quien de todas formas le quedaban pocos días de gobierno, fue un golpe contra el Congreso:

[Leguía] Recordaba su primer gobierno. No había podido realizar obra alguna. Casi la mayoría de sus proyectos habían sido entorpecidos por el Congreso. Había llegado como miembro de un 
partido al Poder, en ese lejano 1908, pero sin ascendiente alguno dentro de la política partidista, el personalismo de los partidos y más aún, de Directivas solamente interesadas en sus posiciones y apetitos personales que habían hecho estéril la obra de gobierno. Sus sucesores también habían vivido esa realidad. Era necesario entonces un cambio (Hooper, 1964, p. 102).

\section{LA ASAMBLEA NACIONAL DE 1919}

El nuevo Presidente Provisorio, Leguía lanzó un manifiesto ese mismo 4 de julio, en el que afirmaba que nada detendría al Perú en la marcha hacia dos ideales: reforma interna y reivindicación de sus derechos, ideas ante las que todo sacrificio sería insignificante. Para alcanzar tales fines, Leguía asumiría el mando por un término de dos meses, convocando a elecciones para conformar una Asamblea Nacional, a fin de modificar la Constitución de 1860. Además, convocó un plebiscito sobre diecinueve puntos a estudiar en la Asamblea Nacional.

\subsection{El plebiscito constitucional}

La idea de reformar la Constitución de 1860 no era nueva. Si bien el proyecto de reforma elaborado en 1897 quedó archivado, el ambiente público tenía la idea reformista desde al menos el primer gobierno de Leguía.

No obstante que la reforma mediante el sistema plebiscitario había sido propuesta desde 1912 por Mariano H. Cornejo, la caída del presidente Billinghurst y el ingreso al poder del primer gobierno militar que encabezó el coronel Óscar R. Benavides impidieron que se llevase adelante el proyecto. El gobierno siguiente de José Pardo no le prestó la atención del caso, de ahí que recayese en Leguía la posibilidad de introducir las reformas que le permitieran eliminar los elementos de control y ejercer ampliamente su autoritarismo (Ramos, 2015, p. 56).

Los diecinueve puntos fueron:

$1^{\circ}$ La renovación del Poder Legislativo será total y coincidirá necesariamente con la renovación del Poder Ejecutivo. El mandato de ambos poderes durará cinco años.

$2^{\circ}$ El Poder Legislativo constará de un Senado compuesto de treinticinco [sic] senadores y de una Cámara compuesta de ciento diez diputados. Este número no podrá alterarse sino por reforma constitucional. Una ley orgánica designará las circunscripciones departamentales y provinciales y el número de senadores y diputados que les corresponda elegir. $3^{\circ}$ Los Senadores y Diputados de la República serán elegidos por voto popular directo.

Solamente en caso de muerte o dimisión del Presidente de la República, el Congreso elegirá dentro de los treinta días, al ciudadano que deba completar el período presidencial, gobernando entretanto el Consejo de Ministros.

Las vacantes del Congreso se llenarán por elecciones parciales.

$4^{\circ}$ El Congreso Ordinario funcionará cuando menos noventa días en el año y ciento veinte cuando más. El Congreso extraordinario será convocado por el Poder Ejecutivo cuando lo juzgue necesario.

$5^{\circ}$ Las Cámaras se reunirán únicamente para instalar sus sesiones, sancionar los tratados internacionales y cumplir las atribuciones electorales que la Constitución asigna al congreso.

$6^{\circ} \quad$ Hay incompatibilidad entre el mandato legislativo y todo empleo público, sea de la administración nacional, sea de la local. Los empleados de Beneficencia o de sociedades dependientes en cualquiera forma del Estado, se hallan incluidos en esta incompatibilidad.

$7^{\circ} \quad$ Los Ministros Diplomáticos serán nombrados por el Gobierno, con aprobación del Senado.

$8^{\circ}$ Las garantías individuales no podrán ser suspendidas por ninguna ley, ni por ninguna autoridad.

$9^{\circ}$ La carrera judicial será determinada por una ley que fije expresamente las condiciones exclusivas de los ascensos.

Los nombramientos judiciales de primera y segunda instancia serán ratificados por la Corte Suprema, cada cinco años.

$10^{\circ}$ La contribución sobre la renta será progresiva.

$11^{\circ}$ Los conflictos entre el capital y el trabajo serán sometidos al arbitraje obligatorio.

$12^{\circ} \mathrm{El}$ Congreso no podrá otorgar gracias personales que se traduzcan en gastos del tesoro, ni aumentar el sueldo de los funcionarios públicos, sino por iniciativa del Gobierno.

$13^{\circ}$ No podrá crearse moneda fiduciaria de curso forzoso, salvo el caso de guerra nacional.

$14^{\circ}$ Habrá tres legislaturas regionales, correspondientes al Norte, Centro y Sur de la República, con diputados elegidos por las provincias al mismo tiempo que los representantes nacionales.

Esas legislaturas tendrán todos los años una sesión que durará treinta días improrrogables. Sus atribuciones serán fijadas por ley especial. No 
podrán ocuparse de asuntos personales en ninguna forma.

Sus resoluciones serán comunicadas al Poder Ejecutivo para su cumplimiento. Si éste las considera incompatibles con las leyes generales o con el interés nacional, las someterá con sus observaciones al Congreso, el que seguirá con ellas el mismo procedimiento que con las leyes vetadas.

$15^{\circ}$ Los Concejos Provinciales son autónomos en el manejo de los intereses que les están confiados. La creación de arbitrios será aprobada por el Gobierno.

$16^{\circ}$ Habrá un Consejo de Estado compuesto de seis miembros con el voto del Consejo de Ministros y con aprobación del Senado. La ley fijará los casos en que el Gobierno debe oír su opinión y aquellos en que no puede proceder contra ella.

$17^{\circ}$ Sólo el Gobierno podrá conceder, conforme a la ley, pensiones de jubilación, cesantía y montepío sin que por ningún motivo pueda intervenir el Poder Legislativo.

$18^{\circ}$ Nadie podrá gozar de más de un sueldo o emolumento del Estado, sea cual fuere el empleo o función que ejerza. Los sueldos o emolumentos pagaderos por instituciones locales 0 por sociedades dependientes en cualquier forma del Gobierno, están incluidos en esta prohibición.

$19^{\circ}$ El próximo Congreso se instalará el 24 de Setiembre de este año, presidido por el Presidente del Senado y funcionará durante 30 días como Asamblea Nacional para promulgar las reformas que resulten aprobadas por el voto plebiscitario.

La renovación total del Legislativo, la delimitación de las circunscripciones departamentales y provinciales por las que se elegiría representantes parlamentarios, la implementación de un nuevo sistema de sucesión presidencial (aunque apostando por el Presidente del Senado), la incompatibilidad de las funciones legislativas con los demás empleos públicos, la fijación de los plazos de funcionamiento de las Cámaras, y las restricciones en la iniciativa parlamentaria en materia de gracias, sueldos y pensiones, eran temas ya propuestos por Billinghurst, encontradas en el proyecto de ley que nunca llegó a promulgar por el pronunciamiento en defensa del Congreso.

Las elecciones presidenciales y congresales se efectuaron el 24 de agosto, y al día siguiente, se realizó la consulta plebiscitaria. Con ello, Leguía "constitucionalizó" su cargo, y más con las leyes que emanaron de la nueva Asamblea Nacional.
El 24 de septiembre de 1919, se instaló solemnemente la Asamblea Nacional, como ya dijimos, presidida por Mariano H. Cornejo. En su discurso, lleno de las ideas sociológicas, a las que era afecto, Cornejo comentó las reformas constitucionales, "inspiradas en el noble empeño de reemplazar el artificio con la verdad". Era evidente que en los espíritus y en la opinión nacional había un deseo de reformar la estructura política y económica del país. Se contemplaba que la realidad nacional no estaba de acuerdo con las estructuras políticas y sociales del momento. Por ello, Cornejo aseguraba que las reformas plebiscitarias no agotaban la obra proseguida, y que la Asamblea las completaría, "inspirándose en el mismo objetivo: hacer del Perú una democracia".

El Perú, en que hay que reformarlo todo y crearlo todo, es el campo abierto, atrayente, incomparable para la labor constructiva de los verdaderos hombres de Estado [...] Sólo una Asamblea y un Gobierno Nacional tienen Título y Derecho para interpretar con sus votos sinceros la fe, el entusiasmo, la esperanza que brota de lo más íntimo de las entrañas de un pueblo, que vive sediento de justicia (Cornejo, 1919).

Y luego, "ejerciendo la plenitud del poder constituyente que le ha conferido el plebiscito", la Asamblea aprobó una moción que se convertiría en la Ley $\mathrm{N}^{\circ} 3083$, promulgada al día siguiente. Con dicha ley, se aprobaban los actos del Gobierno Provisional, declarando fuerza de ley a sus decretos y extendiendo su mandato hasta la proclamación del presidente Constitucional por la Asamblea. Con ello, se daba validez política al régimen leguíista, contribuyendo a dotarlo de mayor firmeza; además, esta ley sería utilizada para avalar las deportaciones que ya había ordenado el régimen.

Luego de elegir la Presidencia de la Asamblea, se designó la Comisión de Constitución, presidida por el senador Javier Prado Ugarteche (Lima), contando con el diputado Clemente Palma (Lima) como Secretario; completaban la comisión, los senadores Pedro Rojas Loayza (Ancash), Germán Luna Iglesias (Cajamarca), Pablo de la Torre (Cuzco) y José Segundo Osorio (Arequipa), y por los diputados Juan M. Torres Balcázar (Lima), Manuel S. Frisancho (Cuzco), Ramón Nadal (Urubamba), Celso Macedo Pastor (Ayaviri), Carlos A. Calle (Moyobamba), Augusto Alva (Contumazá), Alfonso Delgado Vivanco (La Unión), Miguel A. Checa (Piura) y José Antonio Encinas (Puno).

El 30 de septiembre, se dictaminó la aprobación de las reformas plebiscitarias, pidiendo su incorporación a la Constitución. Pero como en 1860, surgió de nuevo la vieja cuestión: ¿la Asamblea era constitucional o 
constituyente? Si era constitucional, la Asamblea se dividiría en dos Cámaras y procedería a la reforma constitucional en dos legislaturas ordinarias, como lo exigía la Constitución. Si era constituyente, debía funcionar en un solo cuerpo y disolverse en seguida. Aníbal Maúrtua, diputado por Pachitea, se preguntaba si la Asamblea sería una "simple reunión de meros amanuenses encargada de catalogar exclusivamente los preceptos del pliego plebiscitario" o si tendría poder deliberante y convencional suficiente para ir a la reforma real de la Constitución de 1860.

Evidentemente dentro de la Asamblea, se delineaban dos tendencias. Una, con Javier Prado a la cabeza, sostenía que la Asamblea tenía poderes constitucionales, tomando en cuenta al plebiscito como la base sobre la cual construir la reforma del Perú. La otra, con representantes provincianos más cercanos al leguiísmo, defendían la intangibilidad de los diecinueve puntos aprobados en el plebiscito. Esta última postura logró triunfar con la Ley $\mathrm{N}^{\circ} 4000$, el 2 de octubre de 1919. Dicha ley declaraba que los diecinueve puntos aprobados en el plebiscito, quedaban incorporados en la Constitución.

Y si faltaba algo más para consolidar al régimen, al día siguiente, el 3 de octubre, se promulgó la Ley N 4001, proclamando Presidente Constitucional a Leguía. Formalmente, aún seguía vigente la Constitución de 1860 que establecía un mandato presidencial de cuatro años, pero esta Ley, en su artículo ampliaba el mandato aduciendo un "período legal" (que jurídicamente se presta a dudas justificadas) de cinco años, desde 1919 hasta 1924.

Días después, el 12 de octubre de 1919, Leguía juraba el cargo de Presidente Constitucional ante la Asamblea Nacional, después que ésta lo había proclamado, por haber obtenido la mayoría de los sufragios válidos en la elección realizada. En esa sesión, Leguía dio cuenta de la actividad desarrollada por el Gobierno Provisorio.

\subsection{El debate constitucional}

El $1^{\circ}$ de octubre de 1919, la Comisión de Constitución había firmado su dictamen en mayoría, incluyendo su Proyecto de Reforma Constitucional.

La Comisión en el desempeño de su encargo, ha procedido haciendo una revisión general de la Constitución vigente, reclamada por la naturaleza misma de las reformas aprobadas por el plebiscito, pues refiriéndose ellas a varios puntos de la Constitución relativos a garantías nacionales e individuales, a los poderes Legislativo, Ejecutivo y Judicial, a la creación de los congresos regionales y Consejo de Estado y autonomía de los concejos provinciales, deben ser integradas, concordadas y complementadas en las secciones y títulos respectivos de la Constitución vigente (Asamblea, 2017, p. 17).

Sin limitarse a las reformas plebiscitarias, la Comisión de Constitución revisó en su totalidad la Constitución de 1860, juzgando que dicha labor estaba en armonía con las funciones propias de la Asamblea, que encarnaba la "voluntad de los pueblos", sobre todo en la etapa que se vivía, "época presente de renovación y de trasformación general de las democracias, en un anhelo de reorganización y de libertad de justicia". La Comisión de Constitución contemplaba ir más allá de las reformas aprobadas en el plebiscito, al incorporar otras reformas dentro de "un plan general de unidad y de orientación nacional", innovando en base a la necesidad razonablemente fundada, buscando dictar "una Carta fundamental, que establezca las normas verdaderas, justas y aplicables a nuestro país, para que haga definitivamente la vida de la democracia y de la ley, propias de pueblos capaces de realizar sus destinos" (Asamblea, 2017, p. 18).

Las reformas aprobadas por el plebiscito popular, han sido incorporadas íntegramente en el proyecto, juzgando a la vez la Comisión que se halla en las atribuciones de la Asamblea, no el oponerse a los preceptos contenidos en algunas de esas reformas, sino dentro de sus mismas disposiciones, completarlas y establecer normas y excepciones en los casos que ellas las reclamen (Asamblea, 2017, p. 18).

Dentro de la Comisión de Constitución, el diputado cuzqueño Frisancho presentó un dictamen en minoría, juzgando que la intención del nuevo Gobierno y del plebiscito eran renovar y no sustituir a la Constitución de 1860, que no estaba dentro de las atribuciones de la Asamblea el dar una nueva Constitución, y que el proyecto de la Comisión de Constitución tendría que pasar al Congreso ordinario para su reforma, conforme a las pautas fijadas en el artículo $131^{\circ}$ de la Constitución de 1860.

Dos días después de la juramentación de Leguía como presidente Constitucional, el 14 de octubre de 1919, con la lectura de los dictámenes de la Comisión de Constitución, iniciaron las discusiones sobre el texto constitucional. Javier Prado pronunció un extenso discurso en defensa del dictamen en mayoría, argumentando que:

[...] el movimiento de julio no sólo fue un movimiento político que derrocó a un Gobierno, sino también un movimiento nacional de renovación y de reformas en sus instituciones [...] el plebiscito tuvo ese mismo sentido, o sea establecer las bases de las demás reformas que 
en la plenitud de sus poderes constitucionales debería sancionar la Asamblea (citado por Pareja, 1954, p. 281).

Tras sustentar la necesidad de la reforma de la Carta de 1860, Javier Prado procedió a sustentar el proyecto de la Comisión de Constitución. Como la Ley $N^{\circ} 4000$, anteriormente mencionada, declaraba la intangibilidad de las iniciativas plebiscitarias y su incorporación sin discusión al nuevo texto constitucional, el debate se reservó para otras iniciativas constitucionales, que mencionaremos conforme revisemos el contenido de la nueva Constitución. Bástenos decir, que fueron materia de discusión temas que ya figuraban en otras normas y que resultaban sobrantes en la nueva Constitución.

Si se tiene que mencionar a los ideólogos principales de la Constitución de 1920, había que destacar a dos figuras: el presidente de la Asamblea Nacional, Mariano H. Cornejo, y el presidente de la Comisión de Constitución, Javier Prado y Ugarteche. Explicar sus trayectorias e ideas, excedería el propósito de estas páginas, pero apuntaremos algunas cuestiones.

En base a su experiencia parlamentaria entre 1889 y 1920, Cornejo quería implementar en el Perú el régimen parlamentario, sosteniendo que el Congreso era la institución fundamental de la democracia, y eso era lo que faltaba en el Perú por causa del gobierno, de los partidos y del ciudadano (Hooper, 1964). Calificado como el "Fouché de la Patria Nueva" (Chanamé, 2015), Cornejo logró introducir ideas como la eliminación de los vicepresidentes y de los congresistas suplentes, la reducción del número de representantes, y la renovación total y simultanea del presidente de la República y del Congreso. En otros puntos, como en la elección del presidente de la República por el Congreso, - la incorporación al texto constitucional de la institución del juicio con jurado, iniciativa que defendía con calor desde 1896, no encontró acogida.

Perteneciente a una de las familias más acaudaladas (y controvertidas) del Perú, Prado había sostenido ideas positivistas y evolucionistas en su juventud, defendiendo el papel clave de la educación en el futuro nacional, a la par que había reflejado ciertos prejuicios contra la población indígena (Prado, 1894). Sin embargo, a lo largo de una larga trayectoria política y académica, el pensamiento de Prado evolucionó hacia las ideas espiritualistas de Bergson. En la Asamblea Nacional, sostuvo reformas en la estructura del Estado en aras de la independencia judicial, la búsqueda de un equilibrio entre el Ejecutivo y el Legislativo. Alejándose de su positivismo juvenil, condenó elocuentemente el maltrato a los indígenas (Pike, 1967).

El 2 de diciembre, se designó una Comisión de Redacción presidida por Cornejo, y el 27 de diciembre de 1919, la Asamblea Nacional clausuró sus sesiones convirtiéndose en Congreso de la República.

Los debates de la constituyente fueron interesantísimos, pero la mayor parte de los mismos se desgastaron en temas como el de la facultad de la Asamblea para alterar la constitución vigente, incorporando solamente en su texto los 18 puntos aprobados por el pueblo en el plebiscito realizado. Hubo representante que dijo que sostener esa tesis era rebajar la función parlamentaria a la de meros amanuenses. Se sostuvo y se aprobó el criterio de que los constituyentes podían haber recibido el mandato de institucionalizar los cambios sugeridos por la revolución de "La Patria Nueva», pero que la amplitud del mandato otorgado les permitía alterar, cambiar e introducir nuevos artículos en la constitución. Agotado el debate, se llegó por esa vía a un criterio transaccional: confeccionar una constitución nueva, respetando los 18 puntos votados por el pueblo (Ugarte del Pino, 1978, p. 496).

\section{LA CONSTITUCIÓN DE 1920}

El texto aprobado por la Asamblea Nacional constaba de 19 títulos y 161 artículos, dentro de los cuales, se incluían cuatro disposiciones transitorias: la Constitución regiría desde el día de su promulgación, sin necesidad de juramento, con lo que se rompía el estilo decimonónico (artículo 158); que la emisión monetaria existente continuaría sometida a las leyes que la crearon y las que pudieran dictarse, debiendo completar la garantía monetaria hasta el íntegro de la emisión (artículo 159); que las reformas de la Constitución se harían por un Congreso ordinario, pero no tendrían efecto si no fuesen ratificadas en otra legislatura, requiriéndose siempre el voto de dos tercios a favor (artículo $160^{\circ}$ ); y que en 1924 , el Congreso se instalaría el 12 de octubre (artículo $161^{\circ}$ ).

La nueva Constitución fue promulgada por el presidente Leguía en una solemne ceremonia el 18 de enero de 1920, desde los balcones de la Municipalidad de Lima. Dos días después, Leguía juraba la nueva Constitución ante el pleno del Congreso.

[Pese a todo, Leguía] no simpatizó nunca con la Constitución que había sido elaborada por la Asamblea [...] Sabía que la Carta que había sido preparada se mantenía siempre dentro de una serie de principios teóricos, divorciados de la realidad. Él hubiera querido que la Constitución plasmara sus ideas, llenas de un realismo pragmático [...] Juró la Constitución y al hacerlo sabía que, más tarde o más temprano, tendría 
que entrar en conflicto con las medidas contenidas en ella. Sabía que tendría que defender su Gobierno y al mismo tiempo hacer progresar a la Nación, y que al no contar con una base legal práctica, se le acusaría de violar la Ley y de atentar contra los sagrados principios de la Democracia (Hooper, 1964, pp. 113-114).

\subsection{El Estado y la Nación}

La Constitución de 1920 fue una versión modificada del texto de 1860, por lo que mucho de su texto fue calcado del anterior, llevando a algunos autores a afirmar que no fueron sino dos grandes pedazos de papel (Ames, 2002).

Continuando con la tradición decimonónica, el nuevo texto constitucional se ocupaba primero de la Nación y el Estado. La Nación fue definida como la asociación política de todos los peruanos (artículo $1^{\circ}$ ), al asegurar la independencia del Perú y prohibir pactos que atenten contra su soberanía (artículo $2^{\circ}$ ), y declarar que la soberanía residía en la Nación (artículo $3^{\circ}$ ).

Por primera vez en el constitucionalismo peruano, se establecían los fines del Estado: defender la independencia de la Nación, mantener la libertad y el orden, y estimular el progreso (artículo $4^{\circ}$ ), texto que recibió críticas de ser innecesario, bajo el argumento de que una Constitución no es un tratado de filosofía política, sino un texto que estructura y organiza el Estado y sus poderes (Pareja, 1954).

Sin duda había en esta Constitución una gran confusión respecto a lo que eran las bases teóricas del Estado y la operatividad del mismo, y se recogió en la carta Constitucional mucho de lo que debía estar en leyes o reglamentos o, inclusive, en las líneas de acción de un partido político. Se confundía el liberalismo político con una concepción social del Estado, con lo que cambiaba radicalmente la figura del "Estado guardián" liberal tornándose en un Estado intervencionista (Guerra, 1994, p. 108).

En lo tocante a las relaciones con la Iglesia, la Comisión de Constitución sostuvo que no había razón para reformar lo dispuesto en la Constitución de 1860, con las reformas de 1915, manteniéndose la redacción de que la religión oficial era la católica y que el Estado la protegía (artículo $5^{\circ}$ ), manteniéndose la libertad de culto asegurada con la reforma constitucional de 1915. No obstante, José Antonio Encinas pidió al firmar el proyecto constitucional, que constase su desacuerdo con esa sección. El texto constitucional de 1920 reconocía así, por primera vez en la historia constitucional peruana, la libertad de conciencia (artículo $23^{\circ}$ ).

\subsection{Los derechos fundamentales}

Al revisar la evolución constitucional peruana hasta 1979, los derechos fundamentales siempre han estado contenidos en nuestros textos constitucionales como "garantías constitucionales", bajo la influencia francesa y española. Hoy, el término "garantías constitucionales" es usado para los instrumentos procesales que sirven para proteger los derechos fundamentales. La Constitución de 1920 estableció tres tipos de "garantías": nacionales, individuales y sociales.

\subsubsection{Las "garantías nacionales"}

Por su importancia en las democracias del momento, el proyecto, y después el texto constitucional, se ocupaba en primer lugar de las garantías nacionales, donde se recogían muchas de las propuestas aprobadas en el plebiscito. Así, nadie tendría empleos o privilegios hereditarios ni fueros personales (artículo $6^{\circ}$ ); todo impuesto (contribución, en el léxico de la época) requeriría ser creada, modificada o derogada por ley (artículo $7^{\circ}$ ); el impuesto a la renta sería progresivo (artículo $8^{\circ}$ ); la ley era irretroactiva (artículo $20^{\circ}$ ).

A diferencia de la Constitución de 1860, en 1920 la pena de muerte se extendía no sólo al homicidio calificado, sino también a la traición a la Patria "en los casos que determina la ley" (artículo $21^{\circ}$ ), lo que implicaba dar carta blanca al legislador en su regulación. No sería bajo el gobierno de Leguía que se implementaría esta disposición, sino bajo la siguiente Constitución, la de 1933, en que se utilizaría la pena de muerte para deshacerse de los rivales políticos.

El texto de 1920 también incluyó garantías fiscales, con principios necesarios para la confianza, respetabilidady prestigio del Estado, como el garantizar el pago de la deuda pública (artículo $10^{\circ}$ ), el prohibir la moneda fiduciaria salvo caso de guerra (artículo $11^{\circ}$ ), y prohibir que nadie gozase de más de un sueldo del Estado (artículo $12^{\circ}$ ).

\subsubsection{Las "garantías individuales"}

Las garantías individuales fueron contempladas por primera vez en los textos constitucionales peruanos. Se buscó suprimir cualquier modalidad de esclavitud en el país, por lo que se prohibía el trabajo personal sin libre consentimiento ni retribución (artículo $22^{\circ}$ ), algo esencial tratándose de la raza indígena, tan explotada por los contratos de "enganche". Se prohibía la prisión por deudas (artículo $25^{\circ}$ ), las confesiones arrancadas a la fuerza (artículo $26^{\circ}$ ), el ejercer la violencia para reclamar el derecho propio (artículo $28^{\circ}$ ). También se añadieron los derechos reconocidos por las Constituciones decimonónicas, como el derecho al 
tránsito (artículo $29^{\circ}$ ), la inviolabilidad del domicilio y del correo (artículos $31^{\circ}$ y $32^{\circ}$ ), y el derecho de asociación (artículo $33^{\circ}$ ).

Por primera vez, se introducía constitucionalmente "el recurso de hábeas corpus por prisión indebida" (artículo $24^{\circ}$ ), un recurso reconocido desde la Resolución Legislativa del 21 de octubre de 1897 y la ampliatoria Ley N ${ }^{\circ} 2253$ del 26 de septiembre de 1916. Pese a todo, esta garantía no sería respetada, teniendo en cuenta el ímpetu represivo del régimen, especialmente en los primeros años, bajo la mano de hierro del ministro de Gobierno y primo del presidente, Germán Leguía y Martínez, el Tigre (Ramos, 2015).

El avance más importante de la Constitución de 1920 en cuanto a los derechos fundamentales, fue la prohibición de que la ley o alguna autoridad pudieran suspender las garantías individuales (artículo $35^{\circ}$ ). Varios publicistas criticaron la medida por considerar, y con razón, que en ciertos casos, era preciso suspender las garantías; incluso, se sostuvo que el artículo $35^{\circ}$ era innecesario puesto que ya existía el recurso de hábeas corpus para frenar cualquier posible desconocimiento de las garantías individuales. No obstante, el problema que se evidenció no fue tanto la idoneidad o no del artículo, sino la desobediencia constante del régimen leguíista, a tal punto, que en 1926, a través de la Ley $N^{\circ} 5470$, el gobierno reformó la Constitución para añadir la posibilidad de suspender las garantías por un plazo máximo de treinta días.

\subsubsection{Las "garantías sociales"}

En la primera mitad del siglo XIX, los movimientos socialistas eran meras ideas confusas, o simples muestras de inadaptación social. Recién después de 1870, comienza la acción organizada e internacional, la preparación técnica y la creación de partidos políticos para alcanzar el poder, dejando la acción directa, el terrorismo, en manos de los anarquistas. La Gran Guerra creó una situación favorable a su expansión, y tal clima se proyectó en el Perú con el potente ciclo huelguístico de fines del gobierno de Pardo, y con la vinculación obrero-estudiantil en la Reforma Universitaria de 1918. El mismo Leguía propuso reformas sociales como candidato, prometiendo en la campaña electoral, la promulgación de una legislación obrera.

La apelación de Leguía a los obreros era más una cuestión de conveniencia política y pragmatismo económico que la creencia en la eficacia de la democratización. No se hacía ilusiones con respecto a la marcha del Perú hacia la democracia. Para él, los trabajadores eran capital humano, un capital que podría traer buenas ganancias si era tratado y conservado apropiadamente (Karno, 1970). Por esas circunstancias, la Comisión de Constitución se orientó por dos ideas básicas: reconocer de forma relativa el derecho a la propiedad, a la industria y al trabajo, condicionándolos con la Constitución y las leyes; y la necesaria intervención del Estado en la vida económica del país. La Constitución de 1920 dedicó un largo capítulo a las "garantías sociales", tomadas en su mayor parte del constitucionalismo alemán, a través de la Constitución de la República de Weimar de 1919, y en su aspecto más nacionalista, del constitucionalismo mexicano, por la Constitución de 1917. De esta forma, se introdujo en el Perú el denominado constitucionalismo social, es decir la inclusión en el texto constitucional de ciertos derechos y postulados a fin de garantizar el bienestar de los ciudadanos en temas como la educación, la salud y el trabajo.

La Constitución de 1920 garantizaba la propiedad, recalcando su sometimiento a las leyes de la República (artículo $38^{\circ}$ ) al margen de la nacionalidad del propietario (artículo $39^{\circ}$ ). También garantizaba la libertad de comercio (artículo $45^{\circ}$ ) y de trabajo (artículo $46^{\circ}$ ), añadiendo que el Estado regularía determinados puntos en relación con dichos derechos. Sin duda por influencia del célebre artículo $27^{\circ}$ de la Constitución mexicana de 1917, la Constitución de 1920 consideró a la propiedad minera de dominio único del Estado, reconociendo a quien la explotase, el derecho de posesión y de usufructo (artículo $42^{\circ}$ ).

Sin embargo, como el país necesitaba (y necesita) capitales e inversiones externas, no se exageraba la nota socialista, estableciendo el rol del Estado como un árbitro en la vida económica, prohibiendo los monopolios privados (artículo 50 ) y estableciendo la obligación del Estado de legislar en materia laboral (artículo $47^{\circ}$ ) y fijar el interés máximo en los préstamos de dinero (artículo 52\%). Además, la Constitución abría al Estado la posibilidad de nacionalizar servicios públicos de propiedad particular, previo pago de una indemnización (artículo $44^{\circ}$ ), y de adoptar providencias para abaratar los artículos de consumo para la subsistencia (artículo $57^{\circ}$ ). Conforme con lo previsto en el plebiscito, se establecía la obligatoriedad del arbitraje en los conflictos entre el capital y el trabajo (artículo $\left.48^{\circ}\right)$.

En suma, no cabe duda que con la Carta de 1920 el contenido y límites de los derechos de propiedad y de libertad de industria y comercio adquirieron connotaciones novedosas a nivel constitucional que cuestionaban los principios más ortodoxos del liberalismo económico. Aun cuando los contenidos socioeconómicos se encontraban dispersos en la parte orgánica y 
dogmática de la Constitución, al igual que en los textos fundamentales precedentes, se comenzaron a perfilar a nivel de declaraciones programáticas las características de un futuro Estado social (Kresalja, 2004, p. 509).

Sobre la educación, la Constitución de 1920 le dedicó apenas dos artículos. El artículo $53^{\circ}$ constitucionalizó lo establecido por la Ley $N^{\circ} 162$ de 1905, que declaraba obligatoria la educación primaria gratuita y obligatoria tanto para hombres como para mujeres, además de hacer al Estado promotor de los establecimientos de ciencias, artes y letras, algo necesario pues si el Estado en el Perú no se preocupa de la cultura ni fomenta la enseñanza superior, no podrá haber una clase política preparada ni ciudadanos conscientes de sus derechos y deberes. El artículo $54^{\circ}$ convertía al profesorado en una carrera pública, con lo que el Estado podría tomar las medidas necesarias para la calidad del cuerpo docente. Sobre el problema indígena, la Comisión de Constitución promovió la idea de dictar leyes especiales para atender el desarrollo, protección y cultura de la raza indígena. Javier Prado dejó de lado las ideas que expuso en su juventud, en relación a la inferioridad de los indígenas (Prado, 1894), al defender "que rehabilitar al indígena es una exigencia que reclama el patriotismo", pues esa "raza de grandes virtudes [...] merece ser defendida y elevada" y había sido tratada en el Perú con rara crueldad. Por ello, se "le garantiza su libertad personal, le asegura el reconocimiento de sus comunidades, ampara su propiedad secular, establece en su favor la enseñanza obligatoria y un mínimo de escuelas" (Pareja, 1954, p. 282).

Una de las reformas más importantes de la nueva Constitución fue declarar la protección de la raza indígena y reconocer las comunidades indígenas (artículo $58^{\circ}$ ). Con ella, se reparaba una injusticia: durante un siglo de legislación liberal, desde los decretos de Bolívar en 1824, pasando por las Constituciones y Códigos anteriores, las comunidades indígenas habían quedado al margen de la ley. Al aceptar su existencia, la Constitución de 1920 se inspiró en un criterio realista, pues estas instituciones responden al sentido colectivista del indígena peruano, con bases en el pasado que se remontan al ayllu incaico y a las reducciones españolas, sirviendo de contrapeso frente a los gamonales y a las autoridades abusivas.

La Constitución de 1920, al reconocer la existencia de las comunidades indígenas y la imprescriptibilidad de sus tierras, refleja una tendencia inequívocamente realista: hasta entonces no existían para el derecho oficial. Es probable que se combinase cierta sensibilidad indigenista, pero también un afán demagógico.
En todo caso, la declaración legislativa abrió una nueva época no solo en la historia jurídica, sino también en la historia social y en la historia económica del Perú. Los preceptos reseñados acusan la influencia de una concepción social del Estado. El liberalismo económico, típico en las cartas decimonónicas, se atenuaba ante una intervención pública más decidida (Ramos, 2015, p. 68).

Estas medidas serían complementadas con medidas como la creación de una Sección de Asuntos Indígenas en el Ministerio de Fomento, la institución del Patronato de la Raza Indígena, el funcionamiento de escuelas en el campo, y el establecimiento del "día del indio". Incluso el presidente Leguía brindaba discursos en quechua, lengua que desconocía. Sin embargo, a la par, dos normas importantes del régimen, en aras de su obsesión de progreso, la Ley $\mathrm{N}^{\circ} 4113$, ley de la Conscripción Vial, y la Ley $N^{\circ} 4891$, ley de Vagancia, no mencionaban directamente a los indígenas, pero acabaron en la práctica, quedando como manchas republicanas.

\subsection{La descentralización}

El régimen centralizado había sido fomentado por el silencio y la postergación del problema en la Constitución de 1860 y en el intento de reforma de 1896; además del fracaso de los intentos descentralizadores anteriores: la descentralización administrativa de 1873 y la descentralización fiscal de 1886 (Zas Friz, 1998). La acentuación de un centralismo absorbente y burocrático, notorio desde los tiempos de Piérola, pese a la subsistencia de las Juntas Departamentales, había creado una fuerte corriente de opinión, formada por el reclamo de las provincias y regiones, pidiendo una legítima participación de las regiones en su propia administración y una cierta intervención en los nombramientos de jueces $y$ funcionarios.

De hecho, en la campaña presidencial, Leguía había exhibido una fuerte preocupación por las regiones, apelando no sólo a los elementos anti centralistas, sino que reflejaba sus propios orígenes provincianos y su afán de armar alianzas con grupos provinciales. Siempre cuidadoso de distinguir entre separatismo y regionalismo, presentó a Inglaterra y los Estados Unidos como ejemplos de crecimiento nacional a través de la administración descentralizada. El desarrollo del Perú, afirmó, dependía de una distribución equitativa de la riqueza total de la nación, para lo cual, según su óptica pragmática, abogó por expandir las comunicaciones interregionales, por establecer zonas militares en donde los destacamentos militares pudieran ayudar a la 
economía local a través de su consumo, mientras que, de paso, preservaban el orden interno, e implementar intensos trabajos de irrigación y colonización (Karno, 1970).

\subsubsection{Los Congresos Regionales}

Para dar una satisfacción a los descentralistas, la Constitución de 1920 recogió una propuesta del plebiscito: los Congresos Regionales. Su labor consistía en legislar de acuerdo con una jurisdicción señalada, sea en el Norte, Centro o Sur de la República. Todos los años se convocarían Legislaturas para esas tres regiones durante un período de 30 días improrrogables (artículo $140^{\circ}$ ).

Las críticas hacia los Congresos Regionales surgieron casi desde el principio, y mayormente desde el Congreso de la República. Y es que la Constitución no definía con precisión sus funciones, por lo que muchas de sus iniciativas, interferían con las funciones del Ejecutivo o del Legislativo.

Una de las monstruosidades de los congresos regionales creados por la Constitución de 1920, fue que tenían poder para dictar resoluciones, pero carecían de órganos para ejecutarlas. No eran entidades administrativas. La Constitución las llamaba legislaturas regionales y, en efecto, realizaban cierta especie de descentralización legislativa, pero no la descentralización administrativa. Sus decisiones, pomposamente calificadas con el nombre de leyes, pasaban al Gobierno para ser vetadas o ejecutadas por él. Lo que hace falta ante todo a las regiones es el poder administrativo propio (Comisión, 2017, pp. 134135).

En respuesta a las críticas, en 1926, los presidentes de los tres Congresos Regionales lanzaron un Manifiesto a la Nación, buscando aclarar la situación.

[...] se afirma que esas Asambleas han hecho una labor completamente estéril; que no aportan ninguna utilidad en la progresiva evolución del país, y no se busca, ni se analiza el origen de esa aseveración superficial e inmotivada. [...] No obstante ello, los Congresos Regionales han cumplido su deber hasta donde sus limitadas atribuciones les permitían [...] No hay ley regional que no advierta y satisfaga una necesidad [...] En éstos y otros sentidos hay, pues, más de un millar de resoluciones dictadas por los Congresos Regionales, de las cuales 675 han sido promulgadas por el Ejecutivo. [...] Pero, ¿de qué nos vale que estas Legislaturas tengan iniciativa en la formación de las leyes al igual que los Poderes Ejecutivos y Judicial, cuando, al pasarlos proyectos de tal origen por el tamiz forzoso del Congreso, algunos Representantes, - no muchos por fortuna - celosos de sus prerrogativas, cuidadosos de su preponderancia política en determinada provincia o departamento trabajan por anularlos, y si ello no fuera posible, por archivarlos indefinidamente? (citado por Tacunan, 2006, pp. 213-214).

Si bien en su primera etapa, los Congresos Regionales mostraron iniciativa y ánimo reformista, paulatinamente se limitaron a ser meros cuerpos burocráticos y peticionarios, falseados por la política, a medida que se prolongaba el régimen leguíista.

Su distribución en las zonas norte, centro y sur comprendían puntos desmesuradamente extensos, sin vinculación ni afinidad entre ellos y reproducían, agravados, los males del centralismo [...] Sus Ilamadas leyes debían tener el pase del Gobierno o del Congreso, si el primero las vetaba [...] No atendían los problemas locales ni las aspiraciones de la región, siendo, en síntesis, una expresión más del centralismo (Pareja, 1954, p. 277).

Al final, los Congresos Regionales no alcanzaron los objetivos propuestos: no aliviaron los males del centralismo ni descongestionaron al Congreso ni tuvo una acción precisa y eficaz ni mucho menos estimuló la vida local, la que se estimuló en cierta medida debido al saneamiento y las carreteras construidas por el régimen de Leguía. No dejó de ser un esfuerzo interesante en aras del sueño descentralizador, pero hacen falta estudios más amplios y detallados sobre estas instituciones.

\subsubsection{Las Municipalidades}

En lo referido al régimen interior de la República, la Constitución de 1920 siguió lo dicho por la Comisión de Constitución, que se preocupaba por dos puntos importantes: para crear nuevos Departamentos y Provincias, serían necesarios los mismos trámites que para una reforma constitucional (artículo $135^{\circ}$ ); y que los funcionarios, que tenían responsabilidad judicial establecida, serían inhabilitados por cuatro años para ejercer cualquier otra función pública (artículo 138 $)$. Sin embargo, el 8 de diciembre de 1919, por la Ley $\mathrm{N}^{\circ}$ 4012, se dispuso la realización de elecciones municipales en toda la República, disponiendo que los alcaldes provinciales fueran elegidos directamente por el pueblo, quedando modificado en este punto el artículo $74^{\circ}$ de la Ley de Municipalidades del 14 de octubre de 1892, que encargaba la elección de las autoridades municipales a los Concejos Provinciales. En dicha ley se autorizaba al ejecutivo nombrar 
Municipalidades Provisionales para que asumieran inmediatamente las labores comunales, hasta la convocatoria a elecciones municipales.

Pero esas elecciones no se realizaron en todo el oncenio de Leguía, por tal razón las municipalidades provinciales se convirtieron en permanentes. Sucesivas leyes (en octubre de 1921, la Ley $N^{\circ}$ 4366; en diciembre de 1923, la Ley $N^{\circ} 4817$; y en febrero de 1925, la Ley $N^{\circ} 5035$ ) fueron prorrogando los efectos de la Ley $\mathrm{N}^{\circ} 4012$, por lo que el Ejecutivo siguió designando a las autoridades municipales en lugar de permitir elecciones municipales libres; peor aún, no se llegó a discutir una nueva Ley de Municipalidades para sustituir a la vetusta de 1892. Recién en 1963, se retornó a la elección municipal, volviendo desde 1970 a estar controlado por el Ministerio del Interior, hasta 1980, desde donde ha existido una continuidad democrática en las elecciones municipales.

\subsection{Los poderes del Estado}

Nuestros textos constitucionales nunca optaron por una forma de gobierno pura. Desde la Constitución de 1856, se introdujeron instituciones del modelo parlamentario a fin de contrapesar el poder presidencial, terminando por generar el hibridismo que caracteriza hasta la actualidad a nuestra forma de gobierno. Y la Constitución de 1920 no fue la excepción.

\subsubsection{El Poder Legislativo}

La primera y principal reforma propuesta en el plebiscito de 1919 fue la renovación total del Poder Legislativo y su coincidencia con el período del Poder Ejecutivo (artículo $70^{\circ}$ ). Para Mariano H. Cornejo, defensor de esta idea desde el gobierno de Billinghurst, "una soberanía que se deja dividir a la hora de manifestarse es una soberanía nominal que no existe en realidad [...] El Cuerpo legislativo que nunca desaparece, es un Poder irrevocable y perpetuo [...] es la negación de la democracia" (citado por Pareja, 1954, p. 276).

La Comisión de Constitución buscó afirmar la autoridad y el control del Poder Legislativo, pero sin exagerar en ese punto, porque no se deseaba crear desequilibrios en la estructura de los poderes públicos y dar pie a conflictos como los de 1914. Además, es un hecho que, en las repúblicas latinoamericanas, todo, desde la psicología hasta la historia y la experiencia, trabajan a favor del régimen presidencial, y los pocos intentos latinoamericanos de crear sistemas parlamentaristas, habían acabado mal, causando agitaciones políticas, crisis económicas y malestar social, conduciendo a la anarquía o a la dictadura. El ejemplo cercano del Chile bajo el régimen parlamentario impuesto tras la guerra civil de 1891, sin duda, influyó en la visión negativa que se tenía de conceder excesiva fuerza al Congreso.

La Constitución de 1920 dispuso una cifra cerrada de 110 diputados y 35 senadores (artículo $72^{\circ}$ ). Con esta medida, por un lado, se obviaba el tradicional criterio de las representaciones por circunscripciones territoriales, y por el otro, se ignoraba la idea de establecer una representación proporcional por distritos electorales. La Comisión de Constitución propuso dos medidas, que serían rechazadas: la introducción del derecho de los expresidentes de la República de ser miembros vitalicios del Senado al concluir su mandato, y el impedimento de los miembros del clero y los militares en actividad para ser representantes.

El texto constitucional fijó también como exigencia constitucional, la aprobación parlamentaria del presupuesto y de los contratos que afecten bienes y rentas generales del Estado (artículo $86^{\circ}$ ), le concedió la facultad de prorrogar sus sesiones ordinarias de 90 hasta 120 días (artículo 78 ${ }^{\circ}$ ), y diversas atribuciones fiscalizadoras de la actividad gubernamental (artículo $\left.83^{\circ}\right)$. De esta forma, ponía fin a la posibilidad de que el Ejecutivo, en caso de demora u oposición del Legislativo, prorrogase el Presupuesto del año anterior, como lo hicieron López de Romaña (1901 y 1903), Leguía (1910 y 1912), Billinghurst (1914) y Pardo (1917). En cuanto a la posibilidad de control político del Congreso sobre el Ejecutivo, la Constitución de 1920 estableció el derecho de los representantes de pedir informes a los ministros por conducto de las Cámaras o por la Presidencia, y la facultad del Poder Legislativo de nombrar comisiones investigadoras de investigación y de información (artículo 99\%). Lo más importante fue prohibir el ejercicio de la cartera al ministro o ministros contra los que las Cámaras emitieran un voto de falta de confianza (artículo $133^{\circ}$ ), con lo cual, se recogió definitivamente en nuestro constitucionalismo, la institución que hoy llamamos "voto de censura", surgida en base a la práctica parlamentaria en 1849. Esta figura sólo se aplicó en dos ocasiones a lo largo de los once años del régimen: en febrero de 1921 contra el ministro de Marina, almirante Juan M. Ontaneda, por asuntos protocolares en relación con una visita oficial de la escuadra norteamericana; y en diciembre de 1926 contra el ministro de Gobierno, José Manuel García, con motivo de un supuesto atentado contra el presidente Leguía.

Conforme con el plebiscito, se recogió la incompatibilidad entre las funciones legislativas $y$ cualquier cargo público, salvo el de ministro de Estado y el desempeño de Comisiones Internacionales (artículo $\left.81^{\circ}\right)$. Sin embargo, esta disposición fue incumplida. Podemos mencionar el caso del diputado arequipeño 
Pedro José Rada y Gamio, uno de los principales personajes del régimen leguíista, quien desempeñó la alcaldía de Lima en 1922, sin por ello, dejar su curul parlamentaria.

\subsubsection{El Poder Ejecutivo}

El liberalismo clásico decimonónico sostenía la primacía del Congreso, con lo cual desbordaba en ocasiones la teoría de la separación de poderes, buscando limitar al Ejecutivo a meras funciones de defensa nacional, protección del orden interno y prestar ciertos servicios de forma subsidiaria a la de la actividad privada. Esta concepción se basaba en la idea de que todo poder es opresivo por la indeclinable tendencia a su abuso, idea reforzada por diversas experiencias. Esta idea llevó a los constituyentes de 1856 y 1867, a la introducción de figuras del modelo parlamentario para frenar los posibles abusos del Ejecutivo. Pero en 1920, con el panorama de la postguerra mundial, se buscaba fortalecer al Ejecutivo con amplia intervención en la solución de los problemas nacionales, pero evitando un eventual despotismo del presidente de la República. Para ello, la nueva Constitución mantuvo la mayoría de las atribuciones de la Constitución de 1860 (artículo $121^{\circ}$ ), pero a la vez, y conforme con las ideas plebiscitarias, aseguró el monopolio del Ejecutivo en cuestiones de pensiones de jubilación, cesantía y montepío (artículo $122^{\circ}$ ).

El presidente de la República, al igual que en las Constituciones decimonónicas, era el jefe del Poder Ejecutivo (artículo $111^{\circ}$ ), representando al Estado en el interior y exterior (artículo $121^{\circ}$ ). Si bien no tenía la denominación de jefe de Gobierno, en los hechos, el presidente de la República ostentaba implícitamente tal carácter. Para ser electo presidente de la República, se conservaban los requisitos establecidos desde 1856: ser peruano de nacimiento, ser ciudadano en ejercicio y tener más de 35 años (artículo $112^{\circ}$ ).

Al igual que en 1834 y 1839, y tomando en cuenta los hechos de 1914, la nueva Constitución suprimió la Vicepresidencia de la República, inspirada en el pensamiento de Mariano H. Cornejo, que la comparó con un individuo almacenando muebles para el caso de incendio, creyendo que el fuego respetaría los muebles de repuesto (Comisión, 2017). Eliminada la Vicepresidencia, la Constitución de 1920 designaba al Consejo de Ministros, como el encargado del gobierno, en caso de muerte o discapacidad del presidente de la República, hasta que el Congreso designase uno interino en un máximo de 30 días (artículos $116^{\circ}$ y $117^{\circ}$ ). Por ello, cuando en agosto de 1930, Leguía se vio en el trance de presentar su dimisión, intentó entregar el gobierno a un gabinete militar, pero dada la convulsa situación de aquellos momentos, fue imposible hacerlo. Continuando con la tradición decimonónica desde 1856, la Constitución de 1920 mantenía la institución del Consejo de Ministros, guardando absoluto silencio sobre el presidente del Consejo de Ministros, quien siguió regulado por las Leyes del 26 de septiembre de 1862 y del 19 de febrero de 1863. Sin embargo, la nueva Constitución mantuvo firme el principio del refrendo ministerial (artículo $127^{\circ}$ ) y la prohibición de ministerios interinos (artículo 128\%), buscando así, en vano, moderar la autoridad presidencial.

Desde la Ley de Ministros de 1862, se estableció que, para designar y remover a los demás ministros, el presidente de la República requeriría la propuesta y el acuerdo del presidente del Consejo (artículo $4^{\circ}$ de la Ley de Ministros de 1862). Pese a ello, la realidad consolidó la práctica que hace del presidente del Consejo tan sólo el primero de los ministros, conformándose con la voluntad presidencial, logrando, en muy limitadas ocasiones, obtener una o dos carteras ministeriales. Bajo la tradición de la autoridad presidencial, era (y aún es) difícil que el presidente de la República dejase de ejercer por si sólo la facultad de escoger a los ministros, en beneficio del presidente del Consejo.

Los ministros de Estado debían resolver sin necesidad de acordar con el presidente de la República, los asuntos referentes al cumplimiento de las leyes y reglamentos relacionados a cada portafolio (artículo $37^{\circ}$ de la Ley de Ministros de 1862). Los ministros presentarían, de común acuerdo con el presidente de la República, los proyectos de ley que creyesen convenientes, interviniendo en su debate parlamentario, de forma individual o colectiva, mas no podían estar presentes en la votación (artículo $130^{\circ}$ ). Además, debían concurrir, tanto individual como colectivamente, cuando el Congreso los invitase para informar sobre su labor (artículo $99^{\circ}$ ).

Pese a todas estas regulaciones, no se pudo revertir la tendencia secular de la preeminencia del presidente de la República. Por ello Manuel Vicente Villarán diría:

Nuestra Constitución y costumbres crean [...] un Presidente fuerte y un Gabinete débil. El Presidente no puede hacer casi nada por sí sólo; necesita un Gabinete que ante la ley comparta con él la autoridad refrendando sus actos. Pero el Presidente domina al Gabinete, porque lo nombra y remueve a voluntad, y las Cámaras, aunque por el voto de censura pueden destruir ministerios, no pueden ni formarlos ni impedir que sean destruidos por voluntad del Presidente... Entre nosotros, al contrario (del sistema europeo parlamentario), la solución del 
desacuerdo (entre el Presidente y los Ministros) es el retiro de éstos. En consecuencia, el Presidente puede hacer política propia. En él reside el centro del poder; los Ministros son sus consejeros y colaboradores mientras el Presidente quiere que sean (Villarán, 1994, pp. 54-55).

El artículo $134^{\circ}$ de la Constitución de 1920 estableció la figura del Consejo de Estado, figura importante de control a las actuaciones del Ejecutivo, existente desde el Estatuto Provisorio sanmartiniano de 1821 hasta su supresión en la Constitución de 1860. La institución diseñada en 1920 estaría compuesta por siete miembros nombrados con el voto del Consejo de Ministros y con aprobación del Senado. Una ley especial debía regular sus funciones: dicha norma, la Ley $\mathrm{N}^{\circ}$ 4024, sería promulgada a fines de enero de 1920, pocos días después de la promulgación de la Constitución. El Consejo de Estado tendría funciones consultivas en temas presupuestales, internacionales, militares, de pensiones. Además, la Ley $N^{\circ} 4152$ estableció que el haber de los consejeros de Estado sería igual al de los representantes parlamentarios. Pero ambas leyes terminaron por quedar inaplicadas: el gobierno nunca efectuó los nombramientos de los consejeros de Estado, y por ende, nunca se instaló el Consejo de Estado.

\subsubsection{El Poder Judicial}

El Poder Judicial había sido durante el ochocientos y las dos primeras décadas del siglo veinte un coto cerrado de las clases altas. Apellidos ilustres, abolengo profesional, prestigio público, conservadurismo y un cierto espíritu de independencia serían sus notas distintivas [...] Incluso el peliagudo asunto de la jurisdicción electoral atravesaría su mejor época cuando se puso en manos de los vocales supremos, en virtud a la Ley 1777, de 16 de diciembre de 1912, el control de la validez de los procesos electorales impugnados. Los fallos de las elecciones entre 1913 y 1917 honraban a quienes las firmaron. Gozaba entonces el más alto tribunal de justicia de un prestigio indiscutible. La relativa prestancia de la magistratura que precedió al Oncenio se graficaría en el desenlace de numerosos conflictos con el poder político (Ramos, 2015, pp. 19-20).

El proyecto de la Comisión de Constitución proponía una reforma crucial en aras de la independencia judicial: la eliminación de la intervención del Ejecutivo en la designación de magistrados, dejando la elección a cargo de la misma Corte Suprema, con alguna intervención del
Legislativo. También proponía la incorporación del control difuso de la inconstitucionalidad de las leyes, surgida en los Estados Unidos y ya aplicada en Argentina y Brasil, con lo que se habría fortalecido notablemente nuestro Estado de Derecho. Además, se buscaba limitar la jurisdicción militar y dotar al Poder Judicial de una base económica independiente, fijando rentas saneadas, recaudadas y aplicadas dentro de una organización especial (Asamblea, 2017).

Sin embargo, los artículos relativos al Poder Judicial en la Constitución promulgada, si bien repetían algunos tópicos anteriores, como su estructuración en cortes y juzgados, la exigencia de la motivación en los fallos, por ejemplo. Pero aunque se estableció la carrera judicial, sujeta a ratificación cada cinco años (artículo $152^{\circ}$ ), lamentablemente se continuó con el sistema establecido en 1860 sobre el nombramiento de los jueces, que hacía del Poder Ejecutivo, el árbitro de las nominaciones judiciales: los magistrados de la Corte Suprema serían elegidos por el Congreso a propuesta del Ejecutivo (artículo $147^{\circ}$ ), en tanto que los jueces de primera instancia serían nombrados, a su vez, por el gobierno a propuesta de la respectiva Corte Superior (artículo $148^{\circ}$ ).

Los primeros años del régimen se vieron marcados por la defensa que la Corte Suprema, en especial su presidente, doctor Carlos Erausquin, hiciera de las garantías fundamentales y las resoluciones judiciales de hábeas corpus ignoradas por la máquina represiva del régimen. Pero paulatinamente, la Corte Suprema fue variando su postura; Leguía no requirió intervenir en el Poder Judicial. Le bastó tener paciencia y esperar a las jubilaciones y fallecimientos, para ir copando la administración de justicia. Los magistrados supremos designados por Leguía, en general, tenían una trayectoria respetable, pero pecaron de sumisión al régimen. En medio del desborde de pasiones y el afán de venganza a la caída del régimen leguíista en 1930, se dispuso cesar a numerosos magistrados; otros serían sometidos a juicio bajo la jurisdicción del inconstitucional Tribunal de Sanción.

El sufragio y el papel del Poder Judicial en los procesos electorales fueron temas de no poca importancia para la Comisión de Constitución, pues a pesar de sus defectos, se juzgó que sería la única garantía eficaz para el derecho electoral (Asamblea, 2017). De hecho, el proyecto de la Comisión de Constitución proponía crear un registro electoral permanente en reemplazo del elaborado en base al registro militar, y encargaba la vigilancia de las elecciones a las Cortes Superiores, y su revisión final a la Corte Suprema (una de las propuestas de Billinghurst en 1914). En contra del proyecto, se argumentó que ello convertiría al Poder Judicial en el 
gran elector, críticas respondidas con el argumento innegable que nuestras fallas electorales provenían de la falta de educación, sentido cívico y moralidad, y que la intervención de la Corte Suprema sería favorable. Al final, se aceptó una solución de compromiso: elección popular directa, jurisdicción limitada del Poder Judicial, y registro permanente (artículos $66^{\circ}$ y $67^{\circ}$ ).

La reforma leguíista evidenciaba, en ese sentido, una mayor sensibilidad al principio de igualdad ciudadana y, en su tiempo, trastocó al sistema electoral de la República aristocrática. Esta medida, aunque fue criticada por demagógica, impracticable y contraria a los hechos que se produjeron, hizo posible un cambio, irreversible desde entonces, en el plano constitucional. Recién se concretaba así de modo definitivo uno de los ideales liberales del siglo XIX (Ramos, 2018, p. 86).

\section{LA CONCULCACIÓN DE LA CONSTITUCIÓN DE} 1920

Los planes de Leguía para la modernización del Perú lo hicieron apostar por el autoritarismo. Evidentemente, y al igual que muchos líderes del siglo XX, consideró la democracia popular como un lujo que un país atrasado no podía permitirse.

\subsection{La visión de Estado de Leguía}

¿Cuál era la idea que tenía Leguía sobre el derecho y el Estado? Don Augusto no dejó obras o ensayos, teóricos o justificativos, como otros mandatarios peruanos. Pensemos en los ensayos económicos de Manuel Pardo y Guillermo Billinghurst, los textos jurídicos de Francisco García Calderón, José Pardo, y José Luis Bustamante, por mencionar a los que vivieron durante la vida de Leguía. De hecho, existen dudas sobre la autenticidad del folleto "Yo tirano, yo ladrón" que circuló con el subtítulo "Memorias del presidente Leguía" en los años 1930. No obstante, sí podemos asomarnos a la visión de estado de Leguía a través del conjunto de sus discursos, recogidos en la colección editada por la Editorial Garcilaso en tres volúmenes entre 1924 y 1926, y en los diversos fascículos que recogían de forma dispersa los eventos importantes de aquellos años, y que circulaban con profusión. En concreto, destaca el discurso pronunciado por Leguía en octubre de 1926 con ocasión de su incorporación a la Academia Peruana de la Lengua correspondiente de la Real Academia Española. Dicho discurso recoge la visión que de la historia nacional y de la política tenía el mandatario lambayecano.

En tal discurso, Leguía inició con una frase rotunda: "Yo no soy un literato y mucho menos un ideólogo". Y es que Leguía, ante todo fue un hombre práctico. De hecho, su preparación académica se limitó a estudios comerciales en Valparaíso, y luego de su participación juvenil en la guerra de 1879, se consagró al trabajo en seguros, agricultura y finanzas, hasta entrar en la política en 1903; ello, no implicaba que fuera un hombre de escasas lecturas: se sabe desde sus años juveniles, que tenía una gran pasión por la lectura. Sin embargo, la vida le llevó por rumbos menos académicos, más financieros. Por ello, Leguía se acercó a los problemas del Perú con la visión de un hombre de negocios, poniendo de manifiesto esta visión, primero como ministro de Hacienda, y luego como presidente de la República. Sus ideas, económicas primero, políticas después, sin duda, fueron decisivas en su alejamiento del civilismo.

De las meditaciones que tales hechos le inspiraron, Leguía quedó convencido de la inutilidad de sistemas teóricos fundados "sobre las hojas muertas de un libro, sin cuidarse de su aplicabilidad a la vida". Por ello, afirmaba que "El problema del gobierno en su aspecto filosófico consiste en armonizar la autoridad con la libertad; pero en su aspecto práctico consiste en adaptar la autoridad a las condiciones étnicas, históricas y sociológicas de un pueblo".

Continuando su discurso, Leguía comentó que al comienzo de la República, se había recurrido al ejemplo romántico de las revoluciones americana y francesa, cuyos líderes habían adoptado las teorías de Montesquieu a fin de asegurar un equilibrio político y establecer libertades. Pero al trasplantarlo a América, los ignorantes caudillos y los ilusos hombres de Estado habían llegado a "los excesos de un raro idealismo al consagrar, en una república de indios, el juicio por jurados $y$, en una patria de analfabetos, el sufragio universal", formando una triste parodia de democracia. De allí, que Leguía concluyese que la historia de la República del Perú "es la historia de un contraste entre la ley que consigna teorías magníficas y la realidad indígena, indócil para someterse a sus principios". Lejos de un gobierno de principios, el Perú vivió bajo un gobierno de pasiones, donde la ley y el gobierno eran los impuestos por el hombre en el poder.

"No fueron nuestras leyes sino los caudillos los que hicieron la Patria" afirmó Leguía. Pero lejos de afirmar que creía en el caudillismo, el presidente continuó afirmando que el antiguo caudillo, exponente de la violenta ambición del individualismo español, había desaparecido. El heroico caudillo había sido sustituido por el "caudillo constructor", con el que evidentemente se identificaba. Si el rol de un líder así, era prosaico y humilde comparado con los heroicos líderes del pasado, era igualmente honorable y quizás más útil: 
En consecuencia, debemos simplificar nuestro mecanismo constitucional, renunciando a los dogmas ingenuos de los estatutos políticos en nombre de reformas concretas. No destruyamos, sino vigoricemos lo que viene, a través de los siglos, como un brote espontáneo de la tierra: el poder fuerte del jefe del gobierno, tanto más eficaz cuanto más durable, porque la Historia demuestra que fue siempre más útil la acción de los caudillos patriotas que la de los llamados gobiernos parlamentarios [...] Y, libertada la estructura política de la fastuosa ornamentación de los principios dialécticos, entreguémonos de lleno a la misión de construir. ¿Y qué campo de acción más aparente y honroso para que ejercite su inteligencia y su voluntad el patriota a quien el veredicto popular imponga en una hora de entusiasmo el grande honor, pero también la enorme responsabilidad, de regir sus destinos? (Academia, 1926, p. 14).

Con ello, Leguía dejaba entrever sus intenciones: un gobierno fuerte, duradero y realista, libre de las restricciones de los mecanismos constitucionales. Las instituciones y las leyes eran meros instrumentos al servicio del gobierno, instrumentos de posible modificación o eliminación en aras del proyecto leguíista, o como Leguía dijo, "acomodar las leyes a las necesidades nacionales, y no someter éstas a la brillante teoría de los sistemas".

El jurista alemán Carl Schmitt, contemporáneo de Leguía, habría calificado al gobernante peruano como un partidario de su teoría del "decisionismo", es decir, la convicción de que los valores y normas en la vida política no pueden seleccionarse por medio de un proceso de deliberación racional entre visiones opcionales del mundo. Valores y normas deben interpretarse y decidirse por quien ejerce el poder (Negretto, 1995). De esta forma, se llevaba a su máximo límite el axioma hobbesiano: Autorictas non veritas facit legem (la autoridad, no la verdad, hace las leyes).

Sin duda, Leguía pensaba que las cosas se debían hacerse, aunque saliesen mal, pero debían hacerse. De ahí que su régimen fuese una dictadura pragmática, como se evidenció en el caso de las polémicas a propósito de los tratados de límites que firmó. Quería convertir al Estado Peruano en uno moderno, con una burocracia más técnica, capaz de asumir un fuerte papel en la economía a través de la creación de redes que comunicasen los centros de producción y los puertos. Para financiar dicho esquema, Leguía apostó por impuestos y empréstitos, consolidando el sistema tributario peruano y aumentando fuertemente la deuda externa, lo que puso su modelo en frágil situación al estallar la depresión mundial en 1929, aprovechada por sus enemigos para derribarlo en 1930 (Contreras y Cueto, 2013).

\subsection{El autoritarismo y las reelecciones}

En el diseño, y en los discursos, los planes de Leguía para una "Patria Nueva" afectaban prácticamente todos los aspectos de la vida peruana. Sin embargo, se concentraban mayormente en el ámbito del progreso material, y si bien pudo acercarse a la idea de "República práctica" defendida medio siglo antes por Manuel Pardo, ésta tenía un sustento doctrinario mucho más sólido que el intento de Leguía, además de una mayor participación ciudadana y un constante apego a la legalidad. El intento de Leguía, al margen de las intenciones modernizadoras, terminó en reforzar los rasgos cortesanos de nuestra vida política.

Con sus sucesivos ministros de Gobierno, Leguía reprimió cualquier signo de oposición efectiva, sin por ello dejar de alabar la democracia, pero sólo en palabras. El Oncenio fue una dictadura, qué duda cabe, un régimen policial y represivo que conculcó tenazmente la misma Constitución que promulgó.

La modernización de la sociedad y del Estado peruano que se opera bajo el gobierno de Leguía está signada, sin embargo, por un marcado autoritarismo del sistema político, que transgrede sistemática y calculadamente al orden constitucional, incluso a la propia legalidad instituida por el régimen; desobedece los mandatos judiciales; aprehende y destierra a sus opositores; menosprecia el consenso; premia lealtades y condena la disensión. Las mismas transformaciones, que los empréstitos cuantiosos canalizan, se llevan a cabo verticalmente, merced a la iniciativa y por obra y gracia del Estado, de arriba hacia abajo, desde el aparato de gobierno hacia la sociedad civil. El autoritarismo no reposa solo en un sistema político que se resiente con el Estado de derecho, sino también en la ideología o, mejor dicho, en la mentalidad que irradia el leguiísmo. No se trata en sí de una ideología con alto grado de articulación simbólica y conceptual; se trata, más bien, de una visión autoritaria simple y práctica dotada de un modesto nivel de elaboración. De esta manera, modernización y autoritarismo se encuentran estrechamente interrelacionados. No podría comprenderse la naturaleza política e institucional del leguiísmo sin abrazar la presencia casi inevitable de estas dos variables (Ramos, 2015, p. 16). 
Buscando su consolidación, el régimen leguíista persiguió a sus opositores desde el principio. Esa mano dura, fue dirigida por el presidente del Consejo de Ministros y ministro de Gobierno, doctor Germán Leguía y Martínez, primo hermano del presidente de la República, apodado El Tigre. Bajo su ministerio, se deportó a numerosos opositores, se vulneró la libertad de información con el caso de la expropiación del diario "La Prensa", y se encarceló a numerosos opositores en la prisión de la isla de San Lorenzo. De hecho, tales abusos le llevaron a entrar en conflicto con el Poder Judicial, lo que motivó una moción de censura en la Cámara de Diputados, de la que logró salir con un voto de confianza (septiembre de 1920).

El artículo $113^{\circ}$ de la Constitución de 1920 establecía que el presidente de la República duraría cinco años en el cargo y sin reelección inmediata, ratificando el artículo $84^{\circ}$ de la anterior Constitución de 1860. Sin embargo, en agosto de 1922, se presentó un proyecto de ley para reformar la Constitución permitiendo la reelección del Presidente de la República, únicamente para el período inmediato. El proyecto necesitaba ser aprobado en dos legislaturas, antes de 1924, en que finalizaba el período de Leguía. En un dictamen breve, la Comisión de Constitución del Senado acogió la idea considerándolo un premio excepcional al mandatario popular, permitiéndole un mayor desarrollo de sus políticas, pero no dejaba de advertir que la reelección indefinida del jefe de Estado, al ser llevada a la práctica, despojaba al sistema republicano de uno de sus rasgos fundamentales, como lo es el carácter temporal de las funciones presidenciales (Basadre, 2005). Tras la aprobación del Senado, la discusión pasó a la Cámara de Diputados, donde terminó por aprobarse.

Germán Leguía y Martínez, que tenía ambiciones presidenciales, se opuso a la idea de la reelección, y renunció el mismo día que la propuesta era aprobada en el Senado (octubre de 1922). Había aglutinado en torno suyo a los elementos más progresistas del leguiísmo, y decidió acudir a la propaganda electoral: en agosto de 1923, lanzó un manifiesto exponiendo su programa político y condenando la reelección.

La reelección [...] humilla el carácter y deslustra la dignidad del mandatario supremo, porque le hace descender de su altura serena y tranquila... lo macula con la tilde de la ambición insaciada; lo envuelve en las sombras de la pasión, la violencia y la parcialidad; personaliza y rebaja sus mejores actos, en que inciden las suspicacias de la desconfianza y la sospecha [...] ahoga las ambiciones lícitas y los derechos democráticos [...] quita a la elección su desenvoltura, al voto su mérito, su eficacia a la acción de las mayorías, que se retraen ante el seguro choque de su esfuerzo contra la presión y el capricho de las energías oficiales; y desvía de su objetivo los dineros del fisco, dándoles aplicación partidarista antojadiza y calculadora [...] Bien está una reelección en pueblos purificados ya por el crisol de libertades ciertas y dilatadas y en los cuales el sufragio y la alteza de las mayorías son tan poderosas y eficientes, que se imponen, cuando así lo deciden al amparo de leyes respetables y respetadas, hasta el punto de excluir y echar por tierra las ambiciones de los que mandan, repeliéndolos y sustituyéndolos a voluntad (citado en Caretas, 1999).

Poco después, conforme con la Constitución, se debatió nuevamente la reforma constitucional que favorecía la reelección, idea que ganó por amplia mayoría, siendo promulgada por el presidente del Congreso, Foción Mariátegui, por Ley N 4687, en septiembre de 1923. Y entre octubre y noviembre, Germán Leguía y sus partidarios fueron detenidos y desterrados, acusados de una conjura contra el gobierno; El Tigre terminó siendo víctima del equipo represor que había establecido y utilizado. Pese a las críticas de Rafael Larco Herrera y Manuel Vicente Villarán, el régimen siguió adelante y en las elecciones de 1924, Augusto B. Leguía fue reelecto con el apoyo del Partido Democrático Reformista, suerte de partido oficial que sustentaría el personalismo leguíista (Ames, 2009).

Si bien dio el golpe de gracia a los moribundos partidos políticos de entonces, Leguía no se preocupó en la construcción de un nuevo grupo político capaz de sustentar política e ideológicamente su esfuerzo modernizador. El éxito del régimen hizo resurgir la tradición latinoamericana de la adulación, llegando a límites extremos, superando el de los libertadores y caudillos anteriores. No es de sorprender la presentación de un nuevo proyecto de reforma constitucional para permitir la reelección indefinida del Presidente de la República, apelando a la necesidad para la "Patria Nueva" de contar con un hombre extraordinario para realizar el prodigio modernizador (Oficina del Periodismo, 1928). El proyecto fue aprobado por unanimidad, y fue promulgado por la Ley N 5857 del 4 de octubre de 1927, gracias a la cual Leguía fue reelecto en 1929, asumiendo su cuarto período presidencial, que debería durar hasta 1934.

En octubre de 1929, pocos días después de que Leguía asumiese su cuarto período presidencial, el crac de Wall Street, conmocionó hasta los cimientos de la economía capitalista. Para el gobierno de Leguía, fue el comienzo del fin, pues la situación económica y el desgaste del régimen, llevaron a cuestionar toda la aparente 
prosperidad y modernización de aquellos once años. Fue cuestión de meses: en agosto de 1930, el comandante Sánchez Cerro se sublevó en Arequipa, con un manifiesto que hacía una recapitulación de todo cuanto era censurable en el "régimen corruptor y tiránico" de Leguía, empezando por lo criticable constitucionalmente: "En el orden constitucional, ha roto la Carta Política, erigiendo en ley suprema la voluntad despótica de un hombre y haciendo del Parlamento un hato de lacayos sumisos y voraces" (Sánchez Cerro, 1930).

Tres días después, fracasado el intento por formar un gabinete militar para renunciar ante el Congreso conforme a la Constitución, la madrugada del lunes 25 de agosto de 1930, Augusto B. Leguía, el ciudadano que más tiempo ha ocupado la Presidencia de la República del Perú, firmaba su renuncia, texto cuya lectura parecería confirmar la sinceridad con la que creía estar labrando el progreso nacional y sus temores por el futuro del Perú (Leguía, 1930). Enjuiciado por un Tribunal de Sanción extrajurídico, y encerrado en condiciones terribles para su edad y dolencias, se le obstruyó el elemental derecho de defensa, y su abogado, Alfonso Benavides Loredo, sufriría persecución por haber asumido la defensa del caído gobernante (Benavides, 1952). El agravamiento de su enfermedad llevó a su traslado al Hospital Naval de Bellavista, donde moriría el 6 de febrero de 1932, en tal pobreza que debieron prestarle el traje para el viaje eterno. Apenas pesaba algo más de 30 kilogramos.

El recientemente desaparecido constitucionalista Enrique Bernales afirmó que de haber Leguía permitido la alternancia en el gobierno, otro hubiera sido su final, hubiera sido más estable el proyecto de modernización que puso en práctica y más rico su legado al Perú. Lo perdió su personalismo, y el país perdió con él una de las mejores oportunidades del siglo XX. Es una de las lecciones que la memoria histórica del Perú no debe olvidar nunca (Bernales, 2012).

En los aspectos más censurables que presenta el Oncenio leguíista, ¿cuánto hubo de culpa del Presidente, de algunos de sus colaboradores o del ambiente que entonces se creó? ¿Es justo echar todas las responsabilidades solo sobre la persona misma de Leguía? La poca cantidad de gente eficaz, sobria y preparada a su alrededor, el exceso de adulación, la falta de consejos y de frenos, la ausencia de voceros independientes y responsables en el Parlamento, el periodismo y la opinión pública que pudieran expresar una crítica constructiva, incrementaron cuanto de condenable pudo haber existido durante el Oncenio (Basadre, 2005, tomo 14, p. 284).

\section{LA IMPRONTA DE LA CONSTITUCIÓN DE 1920 EN EL CONSTITUCIONALISMO PERUANO}

Como vimos anteriormente, la Constitución de 1920 tenía un avanzado criterio social para la época, además de interesantes garantías, en base a la influencia de las Constitución mexicana de 1917 y la alemana de 1919, iniciando el constitucionalismo social en el Perú. Pero se había convertido en un símbolo del Oncenio, representando la voluntad y el designio del régimen derrocado, por lo que, para la opinión pública, tenía que ser reformada, idea postulada en el Manifiesto de Arequipa: "Después que la moralización haya sido entronizada, si lo demandase la voluntad ciudadana nuestra Constitución sería revisada. Pero, siempre la cumpliremos y la haremos cumplir".

Caído Leguía, el Perú viviría una etapa de inestabilidad, hasta marzo de 1931, en que asumió el poder una Junta Nacional de Gobierno presidida por el hacendado apurimeño David Samanez Ocampo, la cual dio los primeros pasos hacia una reforma constitucional convocando en agosto de 1931, a una Comisión para que preparase un anteproyecto de Constitución del Estado. Este grupo fue presidido por el constitucionalista Manuel Vicente Villarán, y estuvo integrado por personalidades destacadas como el diplomático Víctor Andrés Belaúnde, los economistas Emilio Romero y César Antonio Ugarte, los juristas Diómedes Arias Schreiber y José León Barandiarán, y el sociólogo Luis E. Valcárcel.

El Anteproyecto resultante, recogió en buena parte los postulados de la Constitución de 1920 en materia de derechos y garantías. En otros temas buscó limitar el poder del Ejecutivo, acabar con la religión oficial y convertir al Perú en un estado laico. El texto se mantuvo a tono con su época, proponiendo ideas avanzadas, como la participación de los trabajadores en las utilidades de las empresas, la función social de la propiedad, la promoción de la pequeña y mediana propiedad, y la propuesta de una reforma agraria.

Paralelamente a la actividad de la Comisión Villarán, Samanez Ocampo convocó a elecciones para presidente y para un Congreso Constituyente, el cual, en medio de un sangriento ambiente político, que incluyó el arresto y deportación de veintisiete representantes, sublevaciones en varias ciudades, y que culminó con el asesinato del presidente Sánchez Cerro; preparó una nueva Constitución, promulgada en abril de 1933. Este texto constitucional duraría, formalmente, 46 años, en medio de regímenes autoritarios y fugaces momentos democráticos.

5.1. La relación entre el Ejecutivo y Legislativo 
La Constitución de 1933 creó un régimen híbrido entre el presidencialismo y el parlamentarismo, que trabaría el normal funcionamiento político. Fue una reacción contra el abuso del poder presidencial que se vio bajo el imperio de la Constitución de 1920, pero acabó siendo contraproducente: el mal diseño en la relación entre el Ejecutivo y el Legislativo, erosionó la vigencia de la Constitución, y propició en cierta medida el golpe de 1968, lo que llevaría a su muerte sin pena ni gloria en la transición democrática de 1978-1980.

Tal experiencia motivó a los constituyentes de 1978 a corregir los excesos parlamentarios del texto de 1933. La resultante Constitución de 1979 centró el control político en la Cámara de Diputados, concediendo al Ejecutivo el derecho a disolverla en caso de obstruccionismo (artículo $228^{\circ}$ ). La Constitución de 1993 mantiene las atribuciones presidenciales, pero al establecer la unicameralidad del Congreso (artículo $90^{\circ}$ ), rompió con la tradición constitucional peruana establecida en 1828, propiciando el aumento de la demagogia parlamentaria.

\subsection{La reelección presidencial}

Para impedir que se repitiera la experiencia del Oncenio de Leguía, la Constitución de 1933 suprimió el derecho a veto y prohibió la reelección, convirtiendo dicha disposición en una cláusula pétrea, con fuertes castigos a quienes sugiriesen o propusiesen su modificación (artículo 142 ). La Constitución de 1979 mantuvo la prohibición, pero la Constitución de 1993, en su redacción original, la permitió (artículo $112^{\circ}$ ).

Las reelecciones de Fujimori (primero en 1995, y en 2000, luego de la polémica Ley de Interpretación Auténtica) hicieron aflorar el recuerdo de Leguía. Autores críticos al fujimorismo, como el prematuramente desaparecido Pedro Planas (1994), llegaron a comparar al financista lambayecano con el ingeniero nisei, comparación discutible en nuestra opinión (y más la situación carcelaria de cada uno). La crisis de 2000, que terminó por derribar al régimen fujimorista, ha terminado por afianzar en nuestro constitucionalismo, el principio de la no reelección inmediata.

Por otro lado, la Constitución de 1933 siguió al texto de 1920 al abolir las Vicepresidencias de la República, aunque luego serían restauradas tras las reformas plebiscitarias que el general Benavides impulsó en 1939, conservándose la institución vicepresidencial sin cambios en las Constituciones de 1979 y 1993.

\subsection{La independencia judicial}

La Constitución de 1933 mantuvo el mismo esquema de los nombramientos del Poder Judicial, dejándolo como un virtual órgano del Ejecutivo (artículos $222^{\circ}$ y $223^{\circ}$ ); no acogió la propuesta del control difuso de la constitucionalidad de las leyes de la Comisión de 1919, mas si lo permitió para normas infralegales a través de la acción popular (artículo 133º). Su sucesora de 1979 reformó el sistema del nombramiento de los magistrados de justicia, al introducir un ente independiente como el Consejo Nacional de la Magistratura, manteniendo aún cierta intervención del Ejecutivo en dicho proceso (artículo $247^{\circ}$ ), intervención eliminada en la Constitución de 1993 (artículo 150²). La Constitución de 1979, además, estableció un modelo dual de control de la constitucionalidad de las leyes: difuso a través del Poder Judicial y concentrado con el nuevo Tribunal de Garantías Constitucionales; dicho modelo dual ha continuado en la Constitución de 1993, con algunos cambios.

\subsection{La descentralización}

La Constitución de 1933 dejó de lado el modelo de los Congresos Regionales y apostó por la descentralización a través de Concejos Departamentales (artículo $189^{\circ}$ ) y el municipio libre (artículo 203\%), pero nunca se implementaron los primeros, y lo segundo recién se manifestó desde 1963. La Constitución de 1979 apostó por resolver el problema del centralismo, exacerbado en el lapso entre 1930 y 1970, para lo cual, planteó la regionalización, que al final quedó sin implementarse debidamente. El diseño original de 1993 otorgaba poca atención al proceso descentralizador, hasta las reformas de 2002, que permitieron la creación de gobiernos regionales, experiencia que, a la luz de los años, parece también haber sido desafortunada.

\subsection{La situación del indígena}

La Constitución de 1933 mantuvo los derechos sociales recogidos en 1920. La Constitución de 1979 recogió ampliamente el constitucionalismo social, legislando también el régimen económico en razón del interés social. Su sucesora de 1993 redujo la enumeración de los derechos sociales, apostando por la interpretación jurisprudencial, pero aún conserva los derechos heredados desde 1920 en materia social.

Otro tema donde la Constitución de 1933 continuó con el espíritu de la Asamblea de 1919, fue en la ampliación de las normas referentes a las comunidades de indígenas, reiterando el reconocimiento de su existencia legal y de su personería jurídica (artículo $207^{\circ}$ ), decretando garantías para la integridad de sus tierras, fijando su autonomía frente a los Concejos Municipales y estableciendo la necesidad de dictar una legislación tutelar indígena, en base a sus costumbres ancestrales. 
El indigenismo oficial iniciado con Leguía, se mantuvo vigente en cierta forma con la celebración del 24 de junio como "día del indio"; fecha que sería renombrada "día del campesino" a partir de la Reforma Agraria hecha por el Gobierno Revolucionario de las Fuerzas Armadas en 1969, llevando a la identificación del indígena con el campesino, situación problemática hasta nuestros días, principalmente en relación con la identidad étnica. Dicha situación se constitucionalizó en la Constitución de 1979, que pasó a denominar a las "comunidades de indígenas" como "comunidades campesinas y nativas" (artículo $161^{\circ}$ ), recogiendo además otra medida del saliente Gobierno Revolucionario de las Fuerzas Armadas: la declaración del quechua como idioma oficial, al que se añadió el aimara (artículo 83).

\subsection{Las propuestas rechazadas en 1919}

La Constitución de 1933 recogió dos propuestas rechazadas en 1920: la prohibición de la elección parlamentaria de los miembros del clero (artículo $100^{\circ}$ ) y la concesión de un período en el Senado al Presidente Constitucional saliente (artículo $155^{\circ}$ ). En relación con la primera disposición, se permitía la postulación de miembros del clero para los cargos del Ejecutivo, como se vio en el caso curioso del sacerdote Salomón Bolo, candidato vicepresidencial en 1962. En cuanto a la senaduría de los expresidentes, nunca llegó a aplicarse bajo la vigencia del texto de 1933; de hecho, una fuerte polémica surgió cuando en 1955, el expresidente José Luis Bustamante y Rivero, derrocado y exiliado por el general Odría, aún en el cargo, presentó (a través de su abogado Luis Bedoya Reyes) un hábeas corpus ante la Corte Superior de Lima demandando su incorporación al Senado, pedido rechazado en última instancia por la Corte Suprema.

La Constitución de 1979 no recogió la prohibición a los miembros del clero, pero sí recogió la senaduría de los expresidentes constitucionales de la República, pero como un cargo vitalicio (artículo $166^{\circ}$ ). Disfrutaron de tal cargo, los expresidentes Bustamante y Rivero, Fernando Belaúnde y Alan García, hasta la interrupción constitucional de 1992.

La vigente Constitución de 1993, al establecer la unicameralidad del Congreso, no recoge ya ese privilegio para los expresidentes. Tampoco se impide la postulación de los miembros del clero, y la Ley Orgánica de Elecciones se limita a establecer limitaciones para evitar que los religiosos utilicen su ministerio para hacer proselitismo político. Por parte del clero católico, existe la prohibición recogida en el Código de Derecho Canónico; en otras confesiones religiosas, no existe tales impedimentos, lo que ha permitido que en los últimos años, se haya visto a líderes de diversos grupos protestantes actuar en la tribuna parlamentaria.

\section{Conclusiones}

El historiador norteamericano Pike (1967), al estudiar la época del Oncenio, afirmaba que la Constitución de 1920 era el modelo del Perú que nunca fue.

Un profesor extranjero de Derecho Constitucional que examinara la Carta de 1920 y la comparase con las precedentes, ignorando su incumplimiento y su vejamen posteriores, y que no conociera la realidad política que la antecedió, para continuar luego mediatizada durante el Gobierno dictatorial y de fuerza de Leguía, hasta 1930, en que fué derogada por el movimiento revolucionario triunfante, sostendría con fundamento que el Perú había dado un gran paso en la estructuración de su Estado, en la renovación de su organización política y en la reforma de sus vicios políticos (Pareja, 1954, pp. 309-310).

Y es que la Constitución de 1920, como hemos visto en las páginas anteriores, introdujo reformas políticas y sociales consideradas necesarias para superar los problemas que afrontaba el Perú ad portas de celebrar el Centenario de la Independencia. No se le puede considerar una mera adecuación de los puntos del plebiscito de 1919 a la decimonónica Constitución de 1860, pues en su debate se incluyeron propuestas que, con diversa fortuna, han estado presente en nuestros debates constitucionales.

Sin embargo, el mismo régimen que la promulgó, terminó por conculcarla, y ello se debió en mucho a la psicología del presidente Leguía. Hombre pragmático (quizá excesivamente), su obsesión por la modernización del Perú estuvo acompañada por la sistemática transgresión del orden constitucional, y terminó por aferrarse al poder en base a sucesivas reformas al texto constitucional hasta su caída en 1930. Conforme la costumbre, que aún no se ha extinguido totalmente, de considerar a la Constitución como un texto político más que como la norma suprema, el texto de 1920 fue identificado con el gobernante caído, por lo que una de las exigencias de la opinión pública fue su sustitución.

Quizá el principal legado de la Constitución de 1920, fue el haber introducido lo que se ha denominado "constitucionalismo social", al incorporar algunos de los derechos y principios recogidos en la Constitución mexicana de 1917 y en la Constitución alemana de 1919. En esta materia fue continuada, como hemos visto, de distintas formas, con avances y retrocesos, por las Constituciones posteriores, en 1933, en 1979 y en 
1993. Pero el problema principal de estos derechos siempre fue, y sigue siendo, su vigencia real y efectiva. La mayor parte de nuestra historia constitucional está colmada por gobiernos autoritarios, que violaron e ignoraron los derechos de primera generación. El cumplimiento de los derechos de segunda generación tampoco fue una tarea fácil, más al ser un país con serias falencias en cuanto a la consolidación del aparato estatal (como la epidemia que vivimos lo demuestra), lo que ha sido caldo de cultivo para demagogias y populismos.

Bibliografía

AMES ZEGARRA, M. (2002). La Constitución de 1920 y las reelecciones presidenciales de Augusto $B$. Leguía: expresiones de la manipulación del poder del estado durante el Oncenio de Augusto B. Leguía. II Encuentro Metropolitano de Jóvenes Investigadores Sociales. Recuperado de https://web.archive.org/web/20071006093106/ http://www.cholonautas.edu.pe/modulo/upload Ames\%20pon.pdf.

CENTURIÓN, F.R. (2014). Apuntes para la historia constitucional peruana: la crisis constitucional de 1914. IUS Revista de investigación de la Facultad de Derecho, (7), 16-45. Recuperado de http://repositorio.usat.edu.pe/bitstream/usat/1 281/1/lus 2014-

I Doctrina FreddyRonaldCenturionGonzalez.pdf

La Reelección y sus Ayayeros. Revista Caretas. (1999). Recuperado de https://web.archive.org/web/20090620214334/ https://www.caretas.com.pe/1999/1598/articul os/ayayeros.phtml

NEGRETTO, G. (1995). ¿Qué es el decisionismo? Reflexiones en torno a la doctrina política de Carl Schmitt. Revista Mexicana de Ciencias Políticas y Sociales, 40 (161), 49-74.

PERALTA, V. (2001). Un científico en la política peruana. Mariano H. Cornejo, la república aristocrática y la patria nueva, 1895-1920. Revista Complutense de Historia de América, 27, 163-189.

ACADEMIA PERUANA CORRESPONDIENTE DE LA REAL ESPAÑOLA DE LA LENGUA (1926). Discurso de Recepción del Excmo. Sr. D. Augusto B. Leguía, Presidente de la República. Lima: Imprenta Torres Aguirre.

ALTUVE-FEBRES LORES, F. (2006). La Democracia Fuerte. Lima: Quinto Reino.

ASAMBLEA NACIONAL DEL PERÚ (2017). Proyecto de reforma de la Constitución del Perú presentado por la Comisión de Constitución 1919. Lima:
Centro de Estudios Constitucionales del Tribunal Constitucional del Perú.

BASADRE GROHMANN, J. (2005). Historia de la República del Perú (1822-1933). Lima: El Comercio.

BENAVIDES LOREDO, A. (1952). Defensa jurídica de Leguía ante el Tribunal de Sanción. Lima: Tipografía Peruana.

BERNALES BALLESTEROS, E. (2012). La Constitución de 1993: veinte años después. Lima: IDEMSA.

CHANAMÉ ORBE, R. (2015). La República inconclusa. Lima: Derrama Magisterial.

CONTRERAS, C., \& CUETO, M. (2013). Historia del Perú contemporáneo. Lima: Instituto de Estudios Peruanos.

COMISIÓN PRESIDIDA POR MANUEL VICENTE VILLARÁN (2017). Exposición de motivos del Anteproyecto de Constitución del Estado 1931. Lima: Centro de Estudios Constitucionales del Tribunal Constitucional.

DE LA BARRA, F. (1967). Objetivo: Palacio de Gobierno. Lima: Librería Editorial Juan Mejía Baca.

GUERRA MARTINERE, M. (1994). La República 19001948. En DEL BUSTO DUTHURBURU, J. A. (Dir.), Historia General del Perú (tomo VIII). Lima: Editorial Brasa.

HOOPER LÓPEZ, R. (1964). Leguía. Ensayo biográfico. Lima: Ediciones Peruanas.

KRESALJA, B. (2004). La libertad de empresa: fundamento del sistema económico constitucionalizado. Lima: Fondo Editorial PUCP.

JAMANCA VEGA, M. (2015). La Constitución inacabada. Ideas y modelos constitucionales en el momento fundacional del Perú. Primera mitad del siglo XIX. Lima: Fondo Editorial UNMSM.

LUNA, P. F. (2018). El Estado de la "Patria Nueva" o la victoria de las estructuras. En DRINOT, P. (Ed.), La Patria Nueva: Economía, sociedad y cultura en el Perú, 1919-1930 (pp. 35-81). Raleigh: A Contracorriente.

OFICINA DEL PERIODISMO (1928). La obra de Leguía no ha concluido. Lima: Empresa Editorial Cervantes.

PANIAGUA CORAZAO, V. (2009). Manuel Pardo y el Partido Civil. Apogeo y crisis del primer partido político en el Perú. Lima: Fondo Editorial del Congreso del Perú.

PAREJA PAZ SOLDÁN, J. (1954). Las Constituciones del Perú. Madrid: Cultura Hispánica.

PEASE G.Y., F. (1995). Breve historia contemporánea del Perú. México: Fondo de Cultura Económica.

PIKE, F. B. (1967). The modern history of Peru. New York: Frederick A. Praeger. 
PLANAS SILVA, P. (1994). La República Autocrática.

Lima: Fundación Friedrich Ebert.

PRADO Y UGARTECHE, J. (1894). Estado social del Perú durante la dominación española. Lima: Imprenta de El Diario Judicial.

RAMOS NÚÑEZ, C. (2015). Ley y justicia en el Oncenio de Leguía. Lima: Fondo Editorial PUCP.

RAMOS NÚÑEZ, C. (2018). La letra de la ley. Historia de las constituciones del Perú. Lima: Centro de Estudios Constitucionales del Tribunal Constitucional.

TACUNAN BONIFACIO, S. (2006). Los Congresos Regionales (1919-1923 / 1925-1929). Lima: Seminario de Historia Rural Andina - Universidad Nacional Mayor de San Marcos.

UGARTE DEL PINO, J.V. (1978). Historia de las Constituciones del Perú. Lima: Editorial Andina.

VILLARÁN, M. V. (1994). Posición constitucional de los ministros en el Perú. Lima: Cultural Cuzco.

ZAS FRIZ BURGA, J. (1998). La descentralización ficticia: Perú 1821-1998. Lima: Universidad del Pacífico.

BILLINGHURST, G. E. (1914). Proyecto de decreto disolviendo el Congreso, convocando a plebiscito nacional y disponiendo la elección de nuevo

Congreso con facultades constituyentes.

Recuperado de

http://www.congreso.gob.pe/participacion/mus eo/congreso/mensajes/proyecto_decreto disolv iendo congreso eleccion nuevo congreso

CORNEJO, M. H. (1919). Discurso pronunciado por el presidente de la Asamblea Nacional, doctor Mariano H. Cornejo, el 24 de setiembre de 1919. Recuperado

de

http://www.congreso.gob.pe/participacion/mus eo/congreso/mensajes/discurso 24 setiembre 1919

LEGUÍA, A. B. (1919). Manifiesto a la Nación del presidente del Perú, Augusto Bernardino Leguía Salcedo, el 4 de julio de 1919. Recuperado de http://www.congreso.gob.pe/participacion/mus eo/congreso/mensajes/manifiesto_nacion_4_jul io 1919

LEGUIA, A. B. (1930). Dimisión del presidente de la República, Augusto Bernardino Leguía Salcedo, 25 de agosto de 1930. Recuperado de http://www.congreso.gob.pe/participacion/mus eo/congreso/mensajes/dimision_presidente_rep ublica 25 agosto 1930

SÁNCHEZ CERRO, L. M. (1930). Manifiesto a la Nación del Jefe Supremo, teniente coronel Luis Miguel Sánchez Cerro, Arequipa, 22 de agosto de 1930. Recuperado de http://www.congreso.gob.pe/participacion/mus eo/congreso/mensajes/manifiesto nacion 22 a gosto 1930

Constitución del Reich alemán (1919).

Constitución Política de los Estados Unidos Mexicanos (1917).

Constitución Política del Perú (1856).

Constitución Política del Perú (1860).

Constitución Política del Perú (1920).

Constitución Política del Perú (1933).

Constitución Política del Perú (1979).

Constitución Política del Perú (1993).

Ley disponiendo la organización del Consejo de Ministros para la administración de los negocios de Estado. Archivo Digital de la Legislación Peruana. Lima, Perú, 26 de septiembre de 1862.

Ley modificando algunas disposiciones de la ley de ministros. Archivo Digital de la Legislación Peruana. Lima, Perú, 19 de febrero de 1863.

Ley de Municipalidades. Archivo Digital de la Legislación Peruana. Lima, Perú, 14 de octubre de 1892.

Ley N ${ }^{\circ} 162$. Archivo Digital de la Legislación Peruana. Lima, Perú, 5 de diciembre de 1905.

Ley N²193. Archivo Digital de la Legislación Peruana. Lima, Perú, 11 de noviembre de 1915.

Ley N²253. Archivo Digital de la Legislación Peruana. Lima, Perú, 26 de septiembre de 1916.

Ley N ${ }^{\circ} 3083$. Archivo Digital de la Legislación Peruana. Lima, Perú, 25 de septiembre de 1919.

Ley N 4000. Archivo Digital de la Legislación Peruana. Lima, Perú, 2 de octubre de 1919.

Ley N 4001. Archivo Digital de la Legislación Peruana. Lima, Perú, 3 de octubre de 1919.

Ley N ${ }^{\circ} 4012$. Archivo Digital de la Legislación Peruana. Lima, Perú, 8 de diciembre de 1919.

Ley N 4024. Archivo Digital de la Legislación Peruana. Lima, Perú, 31 de enero de 1920.

Ley $N^{\circ} 4113$. Archivo Digital de la Legislación Peruana. Lima, Perú, 11 de mayo de 1920.

Ley $N^{\circ} 4152$. Archivo Digital de la Legislación Peruana. Lima, Perú, 2 de octubre de 1920.

Ley $N^{\circ} 4366$. Archivo Digital de la Legislación Peruana. Lima, Perú, 26 de octubre de 1921.

Ley $N^{\circ} 4687$. Archivo Digital de la Legislación Peruana. Lima, Perú, 19 de septiembre de 1923.

Ley $N^{\circ} 4817$. Archivo Digital de la Legislación Peruana. Lima, Perú, 4 de diciembre de 1923.

Ley N 4891. Archivo Digital de la Legislación Peruana. Lima, Perú, 18 de enero de 1924.

Ley $N^{\circ} 5035$. Archivo Digital de la Legislación Peruana. Lima, Perú, 25 de febrero de 1925.

Ley $N^{\circ}$ 5080. Archivo Digital de la Legislación Peruana. Lima, Perú, 30 de marzo de 1925. 
Ley N5470. Archivo Digital de la Legislación Peruana. Lima, Perú, 28 de septiembre de 1926.

Ley N ${ }^{\circ} 5644$. Archivo Digital de la Legislación Peruana. Lima, Perú, 4 de febrero de 1927.

Ley N ${ }^{\circ}$ 5857. Archivo Digital de la Legislación Peruana. Lima, Perú, 4 de octubre de 1927.

Resolución Legislativa promulgando la ley de Habeas Corpus. Archivo Digital de la Legislación Peruana. Lima, Perú, 21 de octubre de 1897.
AMES ZEGARRA, M. (2009). El Oncenio de Leguía a través de sus elementos básicos (19191930) (Licenciatura). Lima: Universidad Nacional Mayor de San Marcos.

KARNO, H. L. (1970). Augusto B. Leguía, the oligarchy and the modernization of Peru 1870-1930 (Doctorado). Los ÁngelesColocar aquí la metodología 